\title{
MINERAL RESOURCES OF THE EL DORADO AND IRETEBA PEAKS WILDERNESS STUDY AREAS, CLARK COUNTY, NEVADA
}

By

JAMES E. CONRAD 1 , GARY A. NOWLAN ${ }^{2}$

U.S. Geological Survey

and

J. DOUGLAS CAUSEY ${ }^{3}$, MICHAEL S. MILLER ${ }^{3}$

U.S. Bureau of Mines

Open-File Report 91-323

Prepared by the U.S. Geological Survey and the U.S. Bureau of Mines
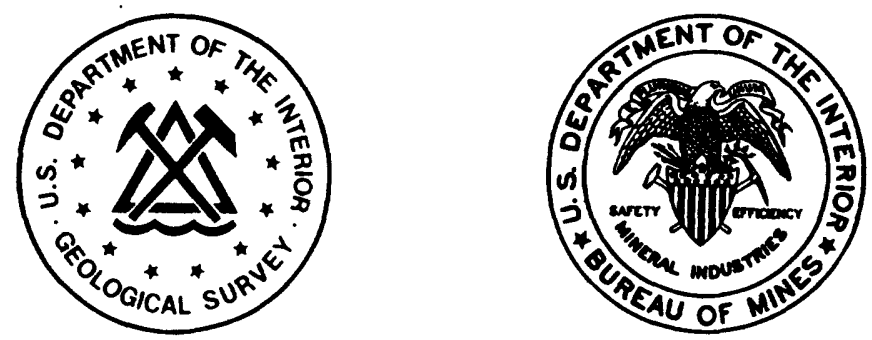

for the U.S. Bureau of Land Management

This report is preliminary and has not been reviewed for conformity with U.S. Geological Survey editorial standards or with the North American stratigraphic code. Any use of trade, product, or firm names is for descriptive purposes only and does not imply endorsement by the U.S. Government

${ }^{1}$ Menlo Park, CA 94025 2Denver, CO 80225

${ }^{3}$ Spokane, WA 99202 


\section{STUDIES RELATED TO WILDERNESS}

\section{Bureau of Land Management Wilderness Study Area}

The Federal Land Policy and Management Act (Public Law 94-579, October 21, 1976) requires the U.S. Geological Survey and the U.S. Bureau of Mines to conduct mineral surveys on certain areas to determine the mineral values, if any, that may be present. Results must be made available to the public and be submitted to the President and the Congress. This report presents the results of a mineral survey of part of the El Dorado (NV-050-423) and Ireteba Peaks (NV-050-438) Wilderness Study Areas, Clark County, Nevada. 


\section{CONTENTS}

\section{Summary 1}

Abstract 1

Character and setting 1

Identified resources of the El Dorado Wilderness Study Area 3

Identified resources of the Ireteba Peaks Wilderness Study Area 3

Mineral resource potential of the El Dorado Wilderness Study Area 3

Mineral resource potential of the Ireteba Peaks Wilderness Study Area 3

Introduction $\mathbf{8}$

Area description 8

Previous and present investigations 8

Acknowledgments 9

Appraisal of identified resources 9

Mining and mineral exploration history 9

Evaluation of prospects in the El Dorado Wilderness Study Area 10

Base and precious metals $\mathbf{1 0}$

Nonmetallic commodities 11

Evaluation of prospects in the Ireteba Peaks Wilderness Study Area 11

Assessment of mineral resource potential 13

Geology 13

Precambrian rocks 13

Tertiary intrusive rocks 14

Tertiary volcanic rocks 14

Tertiary and Quaternary sedimentary rocks 15

Structure 15

Geochemical studies 15

Sampling and analytical methods 16

Results 16

Mineral and energy resource potential of the El Dorado Wilderness Study Area 22

Mineral and energy resource potential of the Ireteba Peaks Wilderness Study

Area 22

References cited 23

Appendixes

Definition of levels of mineral resource potential and certainty of assessment 27

Resource/reserve classification $\mathbf{2 8}$

Geologic time chart 29

TABLES

1. Statistics for selected elements in drainage samples collected in and near the El

Dorado and Ireteba Peaks Wilderness Study Areas, Clark County, Nevada 17

2. Summary of geochemical characteristics of areas of the El Dorado and Ireteba Peaks

Wilderness Study Areas, Clark County, Nevada, based on analyses of samples of stream sediment and panned concentrate derived from stream sediment 19

\section{FIGURES}

1. Index map showing location of El Dorado and Ireteba Peaks Wilderness Study Areas, Clark County, Nevada 2

2. Map showing mineral resource potential and generalized geology of El Dorado

Wilderness Study Area, Clark County, Nevada 4

3. Map showing mineral resource potential and generalized geology of Ireteba Peaks

Wilderness Study Area, Clark County, Nevada 6 


\section{FIGURES--contInued}

4. Map showing geochemical anomalies of El Dorado Wilderness Study Area, Clark County, Nevada 18

5. Map showing geochemical anomalies of Ireteba Peaks Wilderness Study Area, Clark County, Nevada 18 


\title{
MINERAL RESOURCES OF THE EL DORADO AND IRETEBA PEAKS WILDERNESS STUDY AREAS, CLARK COUNTY, NEVADA
}

\author{
By James E. Conrad, and Gary A. Nowlan \\ U.S. Geological Survey \\ J. Douglas Causey, and Michael S. Miller \\ U.S. Bureau of Mines
}

\section{SUMMARY}

\begin{abstract}
At the request of the U.S. Bureau of Land Management, approximately 12,290 acres of the El Dorado Wilderness Study Area (NV-050-423) and 14,994 acres of the Ireteba Peaks Wilderness Study Area (NV-050-438) were evaluated for mineral resources (known) and mineral resource potential (undiscovered). In this report, the areas studied are referred to as the "wilderness study area" or simply "the study area;" any reference to the El Dorado or Ireteba Peaks Wilderness Study Area refers only to that part of the wilderness study area for which a mineral survey was requested by the U.S. Bureau of Land Management. The study areas are located in southern Nevada, approximately $30 \mathrm{mi}$ south of Las Vegas, Nev. No mineral resources were identified in the El Dorado or Ireteba Peaks Wilderness Study Areas. The El Dorado Wilderness Study Area has high resource potential for gold, silver, copper, lead, and zinc in the southern part of the study area and moderate resource potential for gold, silver, lead, and zinc in the central part of the study area. There is low resource potential for these metals in the northern part of the study area. There is moderate resource potential for gold, zinc, cobalt, nickel, tungsten, niobium, and lanthanum and low resource potential for uranium in Precambrian rocks exposed in the southeastern part of the study area. The entire study area has low resource potential for sand and gravel. There is no potential for oil and gas resources. The Ireteba Peaks Wilderness Study Area has moderate resource potential for gold, silver, molybdenum, copper, tungsten, lead, and zinc in the northern and southern parts of the study area. There is low resource potential for uranium, thorium, niobium, lanthanum, and beryl along the western and northern parts of the study area. The entire study area has low resource potential for sand and gravel. There is no potential for oil and gas resources.
\end{abstract}

\section{Character and Setting}

The El Dorado and Ireteba Peaks Wilderness Study Areas lie in the El Dorado Mountains in southern Nevada (fig. 1). The areas comprise a rugged, mountainous terrain with elevations ranging from about 1,960 to $5,072 \mathrm{ft}$. The climate is arid, and vegetation is sparse, consisting of scattered grasses and sagebrush, creosote, Joshua tree, yucca, and several species of cactus including beaver tail, cholla, and barrel cactus.

The El Dorado Wilderness Study Area is underlain by Miocene volcanic rocks faulted against Precambrian gneiss and schist. These rocks are intruded by granitic rocks along the southern boundary of the area. The rocks are cut by numerous north-trending faults. Dikes of varying composition also cut the rocks and have intruded along faults.

The Ireteba Peaks Wilderness Study Area is underlain primarily by numerous dikes and small granitic stocks of Miocene age that intrude Precambrian schist, gneiss, and granite that underlies small parts of the study area. 


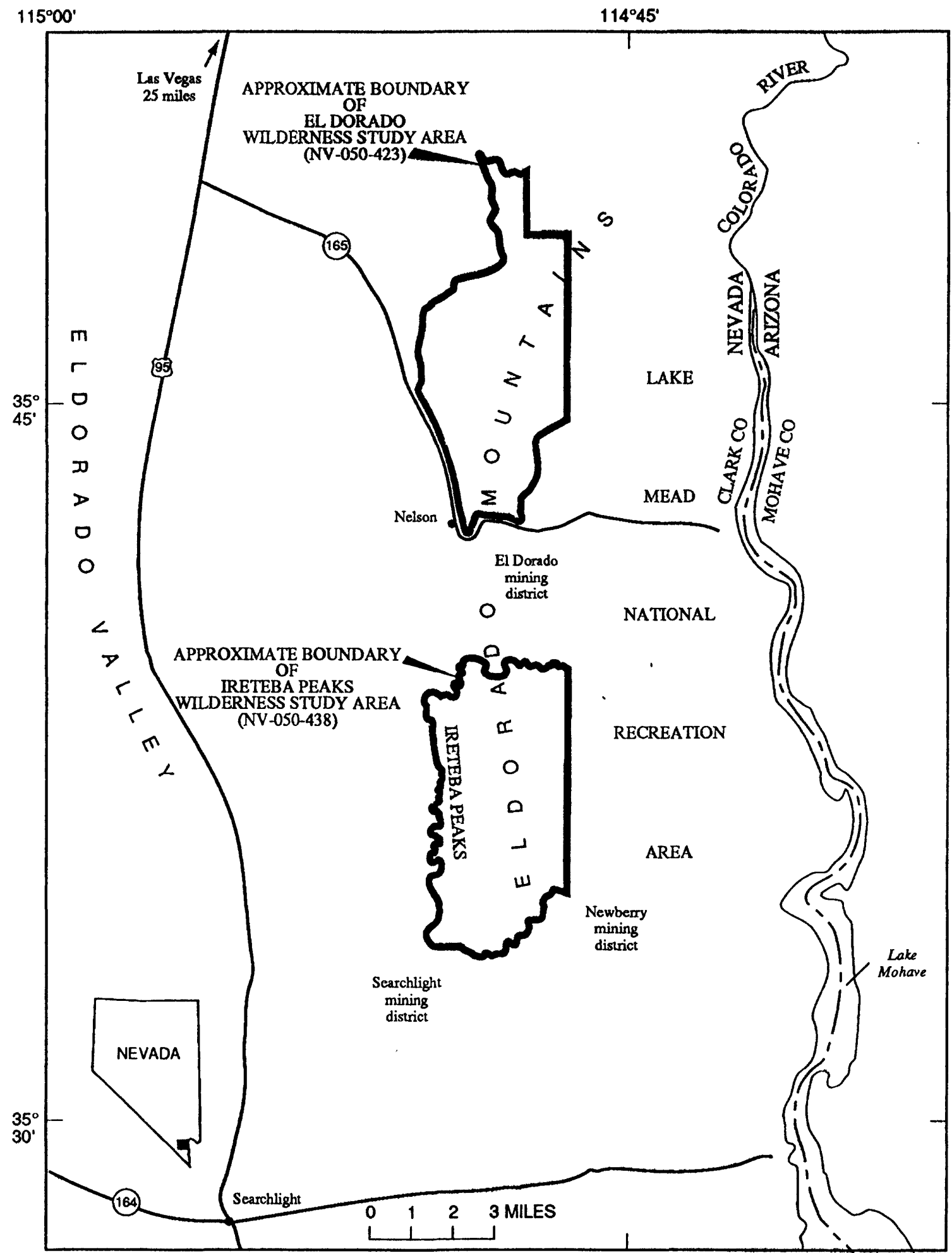

Figure 1. Index map showing location of El Dorado and Ireteba Peaks Wilderness Study Areas, Clark County, Nevada. 


\section{Identifled Resources of the EI Dorado Wilderness Study Area}

There are base and precious metal occurrences on the Paul (gold, silver), Bel (gold, silver), Big Horn-Inez (silver, copper, lead, zinc), and Montezuma (gold, silver, copper, lead, zinc) claims in the study area, but no resources were identified.

Three U.S. Bureau of Land management "material sites" (gravel pits), situated along Nevada State Highway 165, are partly in the study area. The sites extend over both patented and unpatented claims as well as unclaimed lands. On the east side of the area, there is a limited amount of gravel in the dry stream beds and extensive gravel in alluvial fans on the adjacent Lake Mead National Recreation Area. No demand is expected for sand and gravel from within the study area, except adjoining Nevada Highway 165. Road rehabilitation or modification would probably utilize material from the material sites.

A small area containing pumice, a lightweight aggregate, is present on the Eldorado claims, but is too small to be commercial. No radioactive anomalies were found during this investigation, and there are no other indications of uranium resources in the study area.

\section{IdentIfled Resources of the Ireteba Peaks Wilderness Study Area}

During this study, 13 properties were examined. Five are on the study area border and eight are just outside the area, mostly on the west side. No resources were identified in the study area.

Beryl (a source of beryllium) has been reported near the area in pegmatite, but no indication of this mineral was found. A reported uranium anomaly could not be confirmed. Sand and gravel fills valleys outside of the study area on both the east and west sides. Therefore, no demand for the much smaller amount of material which occurs in the drainages of the study area is anticipated.

\section{Mineral Resource Potentlal of the El Dorado Wilderness Study Area}

There is high resource potential for gold, silver, copper, lead, and zinc in the southern part of the study area, and moderate resource potential for gold, silver, lead, and zinc in the central part of the study area in quartz-calcite veins in Tertiary volcanic rocks (fig. 2). Low potential for these metals exists in the northern part of the study area. Precambrian schist and gneiss exposed along the eastern boundary has moderate resource potential for gold, zinc, cobalt, nickel, tungsten, niobium, and lanthanum and low resource potential for uranium. Sand and gravel occur mostly in small deposits suitable for local use; there is low potential for significant resources of these commodities. There is no potential for oil and gas resources.

\section{Mineral Resource Potential of the Ireteba Peaks Wilderness Study Area}

There is moderate resource potential for gold, silver, copper, molybdenum, tungsten, lead, and zinc in the southern and northern parts of the study area (fig. 3). A uranium occurrence has been noted in Precambrian rocks on the west edge of the study area (Garside, 1973), suggesting low potential for uranium resources in these rocks although later studies have been unable to confirm this occurrence. Geochemical studies show an anomalous suite of elements indicating low resource potential for uranium, thorium, niobium, lanthanum, and beryl along the western and northern boundary of the study area. There is abundant sand and gravel on the east and west sides of the study area, but similar deposits are widely available outside the study area and closer to major markets; there is low potential for significant resources of these commodities in the study area. There is no potential for oil and gas resources. 


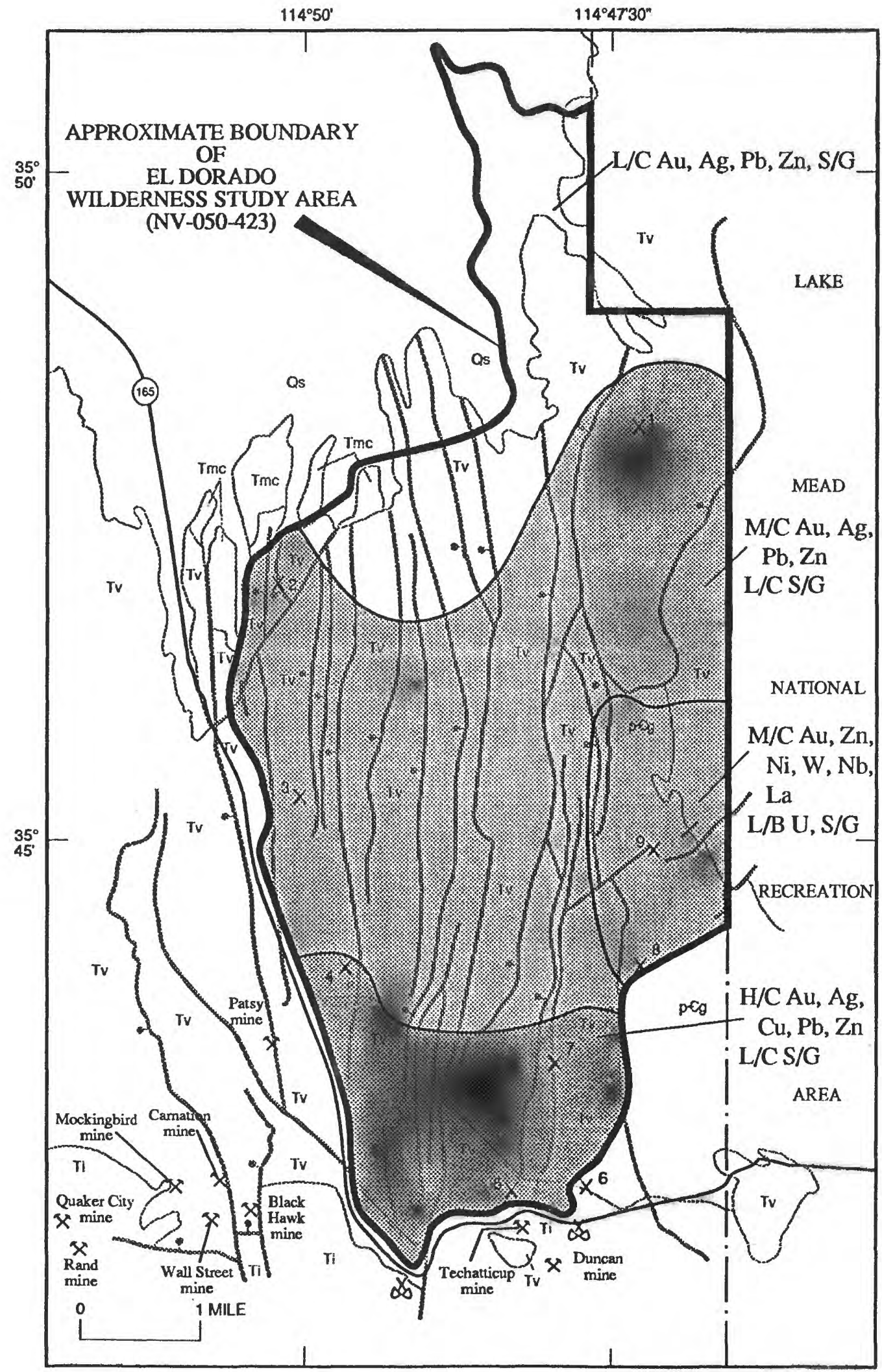

Figure 2. Map showing mineral resource potential and generalized geology of EI Dorado Wilderness Study Area, Clark County, Nevada. 


\section{EXPLANATION}

Area having high resource potential $(H)$

Area having moderate resource potential (M)

Area having low resource potential $(L)$

Levels of certainty of assessment

B Data only suggest level of potential

C Data give good indication of level of potential

父 Mine

$x^{8} \quad$ Prospect--number corresponds to list below

to Quarry

Commodities

Au Gold

$\mathrm{Ag} \quad$ Silver

Co Cobalt

$\mathrm{Cu} \quad$ Copper

La Lanthanum

$\mathrm{Nb} \quad$ Niobium

$\mathrm{Ni} \quad$ Nickel

$\mathrm{Pb} \quad$ Lead

S/G Sand and gravel

U Uranium

W Tungsten

Zn Zinc

Prospects

1. Flintstone claim group

2. Eldorado claims

3. VAR claims

4. SINJUN claims

5. Paul claims

6. Bel claims

7. Rusty Bit claims

8. Big Horn-Inez claims

9. Montezuma claim group

Geologic map units

Qs $\quad$ Surficial deposits (Quaternary)

Tmc Muddy Creek Formation (Tertiary)

$\mathrm{Ti} \quad$ Intrusive rocks (Tertiary)

Tv Volcanic rocks (Tertiary)

p€g Granite, schist, and gneiss (Precambrian)

Contact

Fault--Bar and ball on downthrown side

Figure 2. Continued 


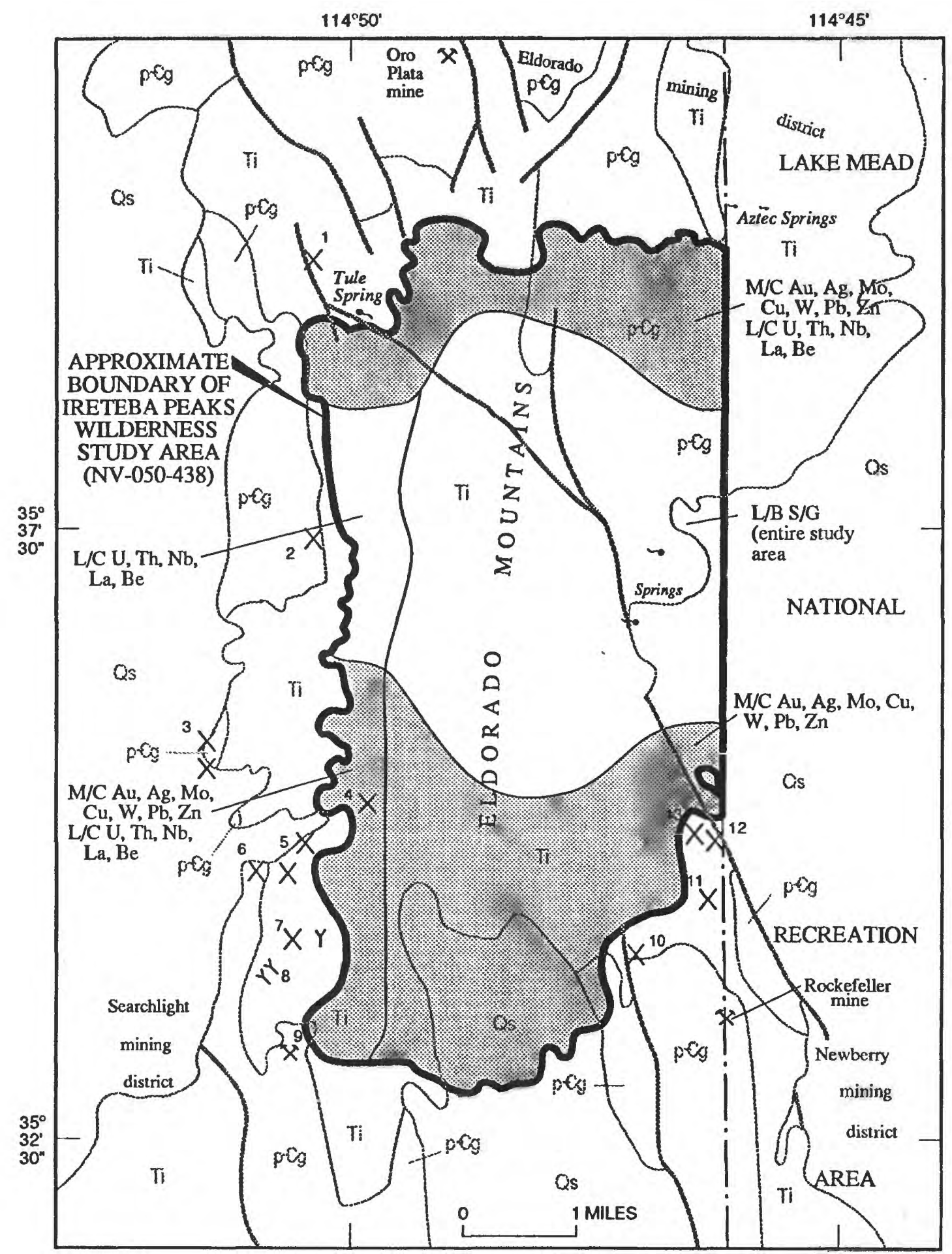

Figure 3. Map showing mineral resource potential and generalized geology of Ireteba Peaks Wilderness Study Area, Clark County, Nevada. 


\section{EXPLANATION}

[2. Area having moderate resource potential (M)

Area having low resource potential (L)

Levels of certainty of assessment

B Data only suggest level of potential

C Data give good indication of level of potential

$x^{9} \quad$ Mine--number corresponds to list below

$x^{1} \quad$ Prospect--number corresponds to list below

Commodities

$\begin{array}{ll}\mathrm{Au} & \text { Gold } \\ \mathrm{Ag} & \text { Silver } \\ \mathrm{Be} & \text { Beryllium } \\ \mathrm{Cu} & \text { Copper } \\ \mathrm{La} & \text { Lanthanum } \\ \mathrm{Mo} & \text { Molybdenum } \\ \mathrm{Nb} & \text { Niobium } \\ \mathrm{Pb} & \text { Lead } \\ \mathrm{S} / \mathrm{G} & \text { Sand and gravel } \\ \mathrm{Th} & \text { Thorium } \\ \mathrm{U} & \text { Uranium } \\ \mathrm{W} & \text { Tungsten } \\ \mathrm{Zn} & \text { Zinc } \\ & \text { Mines and prospects }\end{array}$

1. BMB No. 1 claim

2. H\& E claims

3. Unnamed prospect

4. AJ \#1

5. RJS claims

6. Holsak claims

7. Unnamed prospect

8. Unnamed prospect

9. St. Louis mine

10. Cobalt claims

11. Sarazac claim group

12. Five Spot claims

13. Crystal Lode claim

Geologic map units

Qs $\quad$ Surficial deposits (Quaternary)

$\mathrm{Ti} \quad$ Intrusive rocks (Tertiary)

peg Granite, schist, and gneiss (Precambrian)

- Contact

- Fault

Figure 3. Continued 


\section{INTRODUCTION}

This mineral survey was requested by the U.S. Bureau of Land Management and is the result of a cooperative effort by the U.S. Geological Survey and the U.S. Bureau of Mines. An introduction to the wilderness review process, mineral survey methods, and agency responsibilities was provided by Beikman and others (1983). The U.S. Bureau of Mines evaluates identified resources at individual mines and known mineralized areas by collecting data on current and past mining activities and through field examination of mines, prospects, claims, and mineralized areas. Identified resources are classified according to a system that is a modification of that described by McKelvey (1972) and U.S. Bureau of Mines and U.S. Geological Survey (1980). U.S. Geological Survey studies are designed to provide a reasonable scientific basis for assessing the potential for undiscovered mineral resources by determining geologic units and structures, possible environments of mineral deposition, presence of geochemical and geophysical anomalies, and applicable ore-deposit models. Goudarzi (1984) discussed mineral assessment methodology and terminology as they apply to these surveys. See appendixes for the definition of levels of mineral resource potential and certainty of assessment and for the resource/reserve classification.

\section{Area Description}

The El Dorado and Ireteba Peaks Wilderness Study Areas are located in the El Dorado Mountains in southern Nevada (fig. 1). Mineral surveys were requested for 12,290 acres of the El Dorado Wilderness Study Area and 14,994 acres of the Ireteba Peaks Wilderness Study Area by the U.S. Bureau of Land Management. The areas comprise a rugged, mountainous terrain with elevations ranging from about 1,960 to $5,072 \mathrm{ft}$. The climate is arid, and vegetation is sparse, consisting of scattered grasses and sagebrush, creosote, Joshua tree, yucca, and several species of cactus including beaver tail, cholla, and barrel cactus.

The study areas are located about $30 \mathrm{mi}$ south of Las Vegas, Nev., and adjoin the west edge of the Lake Mead National Recreation Area. The town of Nelson, Nev. lies adjacent to the southwest corner of the El Dorado Wilderness Study Area and is about 4 mi north of the Ireteba Peaks Wilderness Study Area. Access to the west and south parts of the El Dorado Wilderness Study Area is by Nevada state highway 165. Numerous dirt roads branching off this highway provide access to the north and east parts of the study area. Access to the west and north parts of the Ireteba Peaks Wilderness Study Area is by numerous dirt roads branching off U.S. highway 95. Dirt roads branching north of Nevada state highway 164 provide access to the southern and eastern parts of the study area.

\section{Previous and Present Investigations}

The El Dorado and Ireteba Peaks Wilderness Study Areas were included in a regional study of the geology and mineral deposits of Clark County, Nev. (Longwell and others, 1965). Studies of the Tertiary volcanic rocks of the region include those by Longwell (1963) and Anderson and others (1972). A study of the Tertiary tectonics in the region is in Anderson (1971). The Tertiary intrusive rocks and Precambrian metamorphic rocks are discussed in Volborth (1973). Other reports on the mineral deposits of the region include Olson and Hinrichs (1960), Qualheim (1978), Luning and others (1982), Smith and Tingley (1983a, 1983b), U.S. Bureau of Land Management (1983), and Kern and others (1988).

The U.S. Geological Survey conducted field investigations of the El Dorado and Ireteba Peaks Wilderness Study Area in 1987 and 1988. This work included geologic mapping at a scale of 1:62,500, geochemical sampling, and examining outcrops for 
evidence of mineralization. Rock and stream-sediment (including a fine fraction and heavy-mineral concentrate) samples were collected for the geochemical survey. These samples were analyzed for 31 to 37 elements by semiquantitative emission spectrography. Samples were analyzed for gold by atomic-absorption methods, for arsenic, antimony, bismuth, cadmium, and zinc by inductively coupled argon plasmaatomic emission spectrography, and for uranium by ultraviolet fluorimetry. Further details on analytical procedures used for this resource assessment are given in the sections that follow.

The U.S. Bureau of Mines mineral investigations of the study areas (Causey and Miller, 1988; Causey, 1988) included collection of information related to current and past mining activities. Library research included examination of Bureau files and MILS (Mineral Industry Location System). Claim location data were taken from U.S. Bureau of Land Management mining claim records and land status and use records, and county claim records. The field investigation was conducted in the spring of 1987 and spring of 1988. Ninety-one rock samples were collected from the El Dorado Wilderness Study Area. Seventy-three of these samples were analyzed for 18 elements by inductively coupled plasma methods and 18 samples were analyzed for 17 elements by a variety of methods (Causey and Miller, 1988). Ninety-eight rock samples were collected from the Ireteba Peaks Wilderness Study Area. These samples were analyzed at two commercial laboratories by a variety of methods. Analyses were made for 23 elements although no sample was analyzed for all the elements (Causey, 1988).

\section{Acknowledgments}

The U.S. Bureau of Mines authors would like to thank the claimants in the area for their cooperation and valuable information especially Malcolm Figert for his files and tour of his claim, Carman Ridland for his files, Edward Seggerson, Jr. for information on his patented claims, and Alfred Schleicher for information on his claim. The U.S. Bureau of Mines authors also want to thank John Benham, geologist, and Bill Hale, supervisory physical scientist, at WFOC for their assistance in the field.

\section{APPRAISAL OF IDENTIFIED RESOURCES}

By J. Douglas Causey and Michael S. Miller

U.S. Bureau of Mines

\section{Mining and Mineral Exploration History}

The region around and including the study area has been subjected to intense exploration. The Eldorado mining district is located on the south side of the study area. It was organized as the Colorado mining district in 1861 and has since been reported as the El Dorado, Eldorado Canyon, and Nelson mining districts (Raymond, 1872, p. 266; Carlson, 1974, p. 106). The first discovery of gold and silver was either at the present site of the Techatticup mine in 1857 by soldiers from Fort Mohave (Hansen, 1962, p. 218 ) or on the Honest Miner claim, now part of the Rand (or Eldorado Rand) property (Vanderburg, 1937, p. 26). The first mine developed (in 1862 or 1863) was the Techatticup (Tekehetukup), which has been the biggest producer in the district. Mining has occurred, with some breaks, to the present time. In the 1980's, Placer Amax, Inc. and Exxon Corp. entered the district and staked a few claims in the area. In 1988 small heap leach operations were active at the Wall Street mine and on the Techatticup mill tailings. Kern and others (1988) report other active companies in the district in the 1970's and 1980 's including Intermountain Exploration, Amselco, Weaco, and Homestake. 
There are no production records from the district between 1863 and 1873 . Some of the production from the district was reported for the years 1874 through 1897 (Couch and Carpenter, 1943). Hansen (1962, Table X) compiled production records for the years 1874 through 1945. Longwell and others (1965, p. 117) included data up to 1961 . Ransome (1907) estimated gold and silver production before 1906 at $\$ 2$ and $\$ 5$ million worth of gold and silver; Longwell and others (1965) estimated production of $\$ 4.5$ million in gold, silver, copper, lead, and zinc between 1907 and 1961. There are small differences between the reported production by the various authors and by the Bureau of Mines. The value of ore produced since 1874, however, exceeded $\$ 6$ million. Production from the Eldorado district between 1907 and 1981 was at least 98,285 oz gold; 2,264,528 oz silver; $167,893 \mathrm{lb}$ lead; 38,623 lb copper; and 13,898 lb zinc (U.S. Bureau of Mines production records).

Detailed histories of the Eldorado mining district can be found in Vanderburg (1937, p. 26-34), Hansen (1962, p. 182-205), and Longwell and others (1965, p. 116122). Additional historical information can be found in Browne (1868, p. 429), Raymond (1872, p. 266; 1873, p. 186), Ransome (1907, p. 63-79), Hillen (1909, p. 1025-1028), The Mining World (1908a, p. 72; 1908b, p. 460; 1910, p. 724), Hill (1912, p. 201), Lincoln (1923, p. 19-20), Hewett and others (1936, p. 55), Gallagher (1941a, p. 6; 194 lb, p. 5), Ashbaugh (1959a, p. 22-23; 1959b, p. 47-48; 1959c, p. 30-31; 1959d, p. 30-31), and Causey and Miller (1988).

The Searchlight mining district is located on the south and west sides of the Ireteba Peaks Wilderness Study area. The first discovery was in 1897 when the Searchlight vein was found on the Duplex property just southwest of the town of Searchlight (Callaghan, 1939, p. 149-150). Production from the district continued almost without interruption until at least 1962, although little ore was produced after 1954. Total production, nearly all in gold, was estimated to be about $\$ 7$ million (Longwell and others, 1965, p. 112); however, between 1897 and 1902 there are no records. About $\$ 4$ million in production came from just two mines, the Duplex and Quartette (U.S. Bureau of Mines production records).

The Newberry mining district is not well defined. Although it mainly covers claims located in the Newberry Mountains southeast of the study area, there is some overlap with the Searchlight district. Discovered in the 1860 's, this area has had limited production. Total production is probably less than $\$ 200,000$ in gold and silver. The properties around Dupont Mountain, near the southeast edge of the study area, have been included in reports of the Newberry district (Longwell and others, 1965, p. 142,) and the Searchlight district (Vanderburg, 1937, p. 78). The St Louis mine, near the southwest corner of the study area, is listed in descriptions of the Newberry district.

\section{Evaluation of Prospects in the El Dorado Wilderness Study Area}

There are nine mines and prospects in and near the study area (fig.2) which were examined by Causey and Miller (1988). These, along with nonmetallic commodities, have been categorized according to the U.S. Bureau of Mines and U.S. Geological Survey (1980) resource/reserve classification system (see Appendixes).

\section{Base and Precious Metals}

All of the properties examined are inside or straddle the boundary of the study area. Most claims near but outside the study area, including the Techatticup mine (fig. 2), are on private land and were not studied.

The Paul claims overlie intensively fractured and highly chloritized quartz monzonite similar to the host rock at the Techatticup mine. Tension fractures are filled with quartz and associated ore minerals. A large part of the claims is covered by alluvium. Miocene volcanic rocks are on the north side of the claims and do not appear 
to be mineralized. The intrusive rocks on the claims are similar to those at the Techatticup mine and one sample contains $66.4 \mathrm{ppm}$ silver and $1.84 \mathrm{ppm}$ gold.

The Bel (NEL) claims, east of and adjoining the Paul claims, are also considered a good exploration target. Tailings on the claims contain gold and silver which may be recovered during the processing of Techatticup mill tailings by Canyon Mining, Boulder City, Nev. (Lloyd Mooney, 1988, personal commun.). Some altered quartz monzonite is exposed on the claims, but volcanic rock and alluvium cover most of the area. Veins or stockworks in the Nelson Quartz Monzonite of Hansen (1963) may underlie these claims.

The Big Horn-Inez claims overlie Precambrian gneiss cut by granitic dikes and plugs of unknown age. Quartz veins on the claims contain chrysocolla and malachite. No gold was detected in any sample, but copper, silver, lead, and zinc occur in significant amounts associated with quartz veins. One of the claims is also reported to contain uranium (Garside, 1973, p. 37-38) associated with fractures in Precambrian metasedimentary rocks. No indication of uranium was found during this examination. Uranium mineralization apparently is minor, and resources are not expected.

The Montezuma claim group, patented in 1914, overlies Precambrian gneiss and granitic dikes. Mineralized rock is similar to that at the Big Horn-Inez and other lowgrade precious- and base-metal deposits in the Eldorado, Searchlight, and Newberry mining districts (see Causey, 1988). Veins on this property contain gold in addition to silver, copper, lead, and zinc. Although surface tracings are not as extensive as on the Big Horn-Inez, a very low frequency (VLF) electromagnetic survey using a Geometrics EM-16 ${ }^{1}$ indicates the vein system may be longer. A mineralized zone encompassing approximately 20 acres is inferred from sampling.

Twelve samples contained above expected amounts of copper on Flintstone, VAR, and SINJUN claims with the result that they are classified as occurrences.

No indication of metallic resources was found on the other two claims.

Nonmetallic Commodities

BLM has three material sites (CC022889, NV0751, and NV0752) wholly or partially within the study area. These sites were established in 1948 (CC022889) and 1950 (NV0751, NV0752). It is suspected that these sites were used for highway construction and repair. Some gravel was mined from material site NV0752 in late 1987 or early 1988. Material may be required from these sites in the event of future road construction or renovation. Small quantities of sand and gravel are present in washes which drain the study area. However, the majority of the sand and gravel resources in the region are in alluvial fans northwest of the study area, or east, in the Lake Mead National Recreation Area. Pumiceous rock on the Eldorado claims is classified as an occurrence because of small volume and poor access.

\section{Evaluation of Prospects in the Ireteba Peaks Wilderness Study Area}

There are 13 mines and prospects in and near the study area (fig. 3) that were examined by Causey (1988). All of the properties straddle the study area border or are outside of it; no claims or prospects are in the interior. The three nearby properties for which production is reported are the St. Louis, Big Shot, and the Belmont-Phoenix mine (Longwell and others, 1965, p. 180, 200). The St. Louis mine produced \$22,000 worth of gold in 1936 and the Big Shot, apparently near the Sazarac, produced 35 tons of gold ore. The Belmont-Phoenix, shown as being located at the same spot as the BMB No. 1 claim, produced 75,906 oz silver, $286 \mathrm{oz}$ gold, 7,785 lb lead, and $502 \mathrm{lb}$ copper. However, there

\footnotetext{
${ }^{1}$ Use of product name is for information purpose only and does not imply endorsement by the U.S. Geological Survey or the U.S. Bureau of Mines.
} 
are enough differences between reported descriptions of the property and what was observed in the field to lead this author to believe that the Belmont-Phoenix mine is incorrectly located on the USGS Ireteba Peak 7-1/2' topographic map and in Longwell and others (1965). Most maps (e.g. Hansen, 1962, plate 1; Kantor, 1961, plate 1) show a different location for the Oro Plata mine which Longwell and others (1965, p. 180) list as an alternate name for the Belmont-Phoenix.

The Ireteba Peaks study area has no identified resources. Most of the area is underlain by Tertiary granites. Most base and precious metal deposits in the region are in Precambrian and Tertiary igneous and metamorphic rocks which crop out outside or on the borders of the area.

Of thirteen properties examined, five are considered to be significant. One of 21 samples taken from the BMB No. 1 claim contained $19.4 \mathrm{oz} / \mathrm{t}$ silver. Over a $620 \mathrm{ft}$ strike length, silver content ranges from less than $0.1 \mathrm{ppm}$ to $665 \mathrm{ppm}$ and averages $88 \mathrm{ppm}$ $(2.6 \mathrm{oz} / \mathrm{t})$. The property contains 4 adits, two shafts, a trench, two prospect cuts, and two prospect pits. The workings are in a north-northwesterly trending mineralized breccia zone that is near the intersection of the Tule Springs fault and another fault bounding the Ireteba Peaks horst (Volborth, 1973, plate 1). The breccia zone may be either a pipe-like body formed at the intersection of two faults or an elongate opening in the Tule Springs fault and not associated with the block faulting in the region. Further exploration is recommended to determine if a mineable silver deposit can be developed.

The H \& E (Doodle Bug) claims reportedly contain a uranium prospect (Garside, 1973, p. 38), but copper oxides are the dominant minerals. High grade copper samples were collected from dumps of small prospect pits and shafts. As much as 9 percent copper was found in stockpiles (normally about a ton) on the dumps. The property contains one shaft, one adit, and eight prospect pits. The workings are in Precambrian gneiss, granitic pegmatite, and mafic dikes, but the copper minerals are restricted to the gneiss. The area that contains the mineralization is about $100 \mathrm{ft}$ wide by $800 \mathrm{ft}$ long. Most of the copper is found in pods less than $10 \mathrm{ft}$ in diameter. While some of the pods are conformable to foliation, others cut foliation and appear to be associated with small scale faulting of intensely deformed gneiss.

The Cobalt claim group consists of 36 claims along and mostly outside of the southern boundary of the study area. The workings consist of six shafts, three adits and six prospect pits and predate the present claims. No production has been recorded. Maximum assay results are $0.192 \mathrm{oz} / \mathrm{t}$ gold, $0.203 \mathrm{oz} / \mathrm{t}$ silver, 0.96 percent lead, and 0.43 percent zinc. Cobalt ranges from 1 to $20 \mathrm{ppm}$. Widely scattered faults contain low-grade mineralized material. The mineralization appears to be localized in the Precambrian gneisses and associated granitic rocks and does not continue into the Tertiary granite pluton adjoining it on the north. An extensive soil and rock geochemical sampling program along with geophysical exploration techniques are recommended for this area.

The Sazarac claim group (Sazarac, Bornite, Rainbow, Crysocolla, Maine, Copper Queen, and Copper Carbonate) was patented in 1913. The main working is currently called the Rockefeller mine. Although no production is recorded, it is possible that gold was mined in the late 1800 's or early 1900's before records were kept. High gold assays were obtained from surface samples. One sample has $7.577 \mathrm{oz} / \mathrm{t}$ gold and two samples contain more than $0.7 \mathrm{oz} / \mathrm{t}$. The claims overlie Precambrian gneissic rocks with small granitic to quartz monzonitic intrusive bodies. Small quartz veins and faults are widely scattered over the claim area. Also, malachite, azurite, and chrysocolla are present throughout the area. Weakly disseminated copper minerals occur near the common corner of the Crysocolla, Rainbow, Copper Queen, and Maine claims. Because the workings were inaccessible, it could not be determined if the ore was mined out, but it is probable that all the high grade gold ore was removed. Additional exploration for disseminated copper-gold minerals and buried vein deposits is recommended for the area. 
The St. Louis mine was not examined in detail. The workings contain extensive stopes and are not considered safe. One sample indicates that there was high gold content in the veins.

Beryl has been reported from a pegmatite on the west edge of the study area, but beryl was not found during this or an earlier U.S. Bureau of Mines investigation, nor was beryllium found in a previous sampling program. The pegmatite from which the beryl was reported is small and no beryl has been found in other pegmatites in the area. Beryl may occur at depth in these pegmatites, but at present no resources can be identified.

Although radioactive anomalies have been reported on the west edge of the study area, no strong radioactivity was noted during this investigation. A Geometrics Model GR-101A ${ }^{1}$ scintillometer used during this examination did not read over $150 \mathrm{cps}$ on any traverse and generally measured 50 to $75 \mathrm{cps}$. It is assumed that the deviations which occurred were due to variations in rock type and age and terrain affects.

Sand and gravel are present in washes which drain the study area. However, the alluvial fans, which contain the majority of the sand and gravel resources in the region, are outside of the study area adjoining Highway 95 on the west and Lake Mohave on the east. Therefore, any demand for this material could be satisfied from sources adjacent to the area.

\section{ASSESSMENT OF MINERAL RESOURCE POTENTIAL}

By James E. Conrad, and Gary A. Nowlan

U.S. Geological Survey

\section{Geology}

The geology of the El Dorado Mountains consists of a complex assemblage of Precambrian metamorphic rocks, Tertiary intrusive complexes, and Tertiary volcanic rocks that have been cut by numerous high- and low-angle faults. These rocks are flanked by Tertiary and Quaternary fanglomerate in basins adjacent to the range. The El Dorado Wilderness Study Area is underlain by Precambrian metamorphic rocks which are overlain and faulted against Tertiary volcanic rocks (fig. 2). The Ireteba Peaks Wilderness Study Area is underlain primarily by Tertiary granitic rocks; Precambrian rocks occur in the northeastern part of the study area and as small roof pendants in the granitic rocks (fig. 3).

\section{Precambrian rocks}

Precambrian rocks in the El Dorado Mountains consist primarily of gneiss, in part garnetiferous, schist, and granitic rocks. The gneiss consists of augen gneiss containing plagioclase porphyroclasts up to 0.5 in. across in a granular matrix of biotite and quartz. It is highly folded and contains numerous cross-cutting quartz veins. The schist typically consists of fine-grained quartz-biotite schist. Precambrian granitic rocks include hornblende gabbro, hornblende-biotite diorite, and biotite granite. Pegmatites and aplites are common in these rocks and locally occur as swarms.

\footnotetext{
${ }^{1}$ Use of product name is for information purpose only and does not imply endorsement by the U.S. Geological Survey or the U.S. Bureau of Mines.
} 
Tertiary intrusive rocks underlie the extreme southern part of the El Dorado Wilderness Study Area and most of the central part of the Ireteba Peaks Wilderness Study Area. These rocks range in composition from granite to gabbro, but leucocratic granite, adamellite, and quartz diorite are most common.

The Techatticup pluton (Anderson, 1971) is exposed in the extreme southern part of the El Dorado Wilderness Study Area and is the host rock for most of the mineralization in the Eldorado district. This pluton intrudes rocks as young as the upper part of the Patsy Mine Volcanics indicating that it is younger than about $16 \mathrm{Ma}$. Potassium-argon (K-Ar) ages ranging from $14.5 \pm 0.4$ to $16.9 \pm 0.3 \mathrm{Ma}$ were obtained from exposures of this body about $3 \mathrm{mi}$ west of the study area (Anderson and others, 1972). Numerous north-trending dikes with compositions ranging from rhyodacite to andesite are present in the El Dorado Wilderness Study Area; many of these have intruded along the north-trending faults that cut the study area.

Tertiary granitic rocks underlie most of the Ireteba Peaks Wilderness Study Area. These rocks include plutons of varying composition and an intrusive dike complex in the north-central part of the study area. The plutons in the southern and northwestern parts of the study area include fine- to coarse-grained muscovite granite, two-mica garnet-bearing granite, biotite-hornblende rapakivi granite, quartz monzonite, and diorite. The intrusive complex comprises rock of dioritic to tonalitic composition and lighter-colored, finegrained seriate to porphyritic biotite granite. These rock types intrude each other, alternating in a series of north-trending dikes and pods about 5 - to $20 \mathrm{ft}$ thick that dip about $60^{\circ}$ to the east.

\section{Tertiary volcanic rocks}

The Patsy Mine Volcanics unconformably overlie the Precambrian rocks although in most places in the study area the contact of the volcanic rocks with Precambrian rocks is a fault. Where exposed, the original depositional contact is marked by a basal conglomerate unit several tens of feet thick. The Patsy Mine Volcanics comprises a section of ash-flow tuffs and lavas that is about 13,000 ft thick at its type section near the town of Nelson, Nev. (Anderson, 1971). This unit is informally divided into three members by Anderson (1971). The lower member is about $8,000 \mathrm{ft}$ thick and consists of pyroxene-olivine lava flows and flow-breccia and minor interbedded tuffaceous sedimentary rocks. The middle member, about 3,000 ft thick, consists primarily of rhyolite lavas and ash-flow tuff and interbedded tuffaceous sedimentary rocks. The upper member, about $2,000 \mathrm{ft}$ thick, consists of pyroxene-olivine andesite flows similar to those of the lower member, but also contains several rhyolite flows and ash-flow tuffs. Within the study area, this unit is cut by numerous north-trending faults that repeat parts of the section and have tilted the section about $30-40^{\circ}$ to the east. $\mathrm{K}-\mathrm{Ar}$ ages for flows in this unit ranging from $14.5 \pm 0.6 \mathrm{Ma}$ to more than $40 \mathrm{Ma}$ are reported by Anderson and others (1972); however, ages older than about $20 \mathrm{Ma}$ are thought to be anomalously old and result from contamination of older material incorporated into the flows. Anderson and others (1972) considered the best age for this unit to range from 14.5 to $18.6 \mathrm{Ma}$, indicating an early to middle Miocene age.

The tuff of Bridge Spring conformably overlies the Patsy Mine Volcanics in the central part of the El Dorado Wilderness Study Area. This unit consists of welded rhyolite ash-flow tuff containing phenocrysts of sanidine, plagioclase, pyroxene, biotite, and accessory sphene and magnetite and is about $800 \mathrm{ft}$ thick. Anderson and others

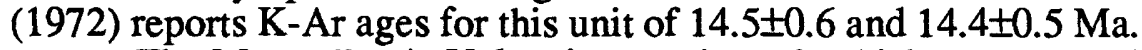

The Mount Davis Volcanics consists of a thick sequence of dark-brown to blackweathering basalt and andesite flows named for exposures at Mount Davis, about $20 \mathrm{mi}$ southeast of the study area (Longwell, 1963). Maximum thickness of this unit may 
exceed 4,000 ft (Longwell, 1963). The Mount Davis Volcanics underlie most of the northern part of the El Dorado Wilderness Study Area, where the section lies above the tuff of Bridge Spring with an angular discordance of about $20^{\circ}$. The unit consists mainly of fine-grained, dark brown to black glassy basalt containing phenocrysts of olivine commonly rimmed with iddingsite. Some flows contain sparse phenocrysts of plagioclase and pyroxene. Also present are flows of fine-grained gray andesite containing phenocrysts of plagioclase, pigeonite, and augite. Several rhyolitic ash-flow tuffs are present in the section; these flows contain phenocrysts of quartz, sanidine, and biotite in a matrix of perlitic glass. K-Ar ages for this unit ranging from $14.6 \pm 0.3$ to $11.8 \pm 0.5 \mathrm{Ma}$ are reported by Anderson and others (1972), indicating a middle Miocene age.

\section{Tertiary and Quaternary Sedimentary Rocks}

The extreme north part of the El Dorado Wilderness Study Area is underlain by basin-fill deposits of Tertiary and Quaternary age consisting of consolidated to unconsolidated, poorly sorted to unsorted, coarse and fine detritus derived from adjacent highlands. The older lithified deposits were assigned to the Tertiary Muddy Creek Formation by Anderson (1971). Younger sedimentary deposits occur throughout the study areas and include alluvial fans along the edge of the El Dorado Mountains, unconsolidated sand and gravel in stream bottoms, and unconsolidated rock debris on gentle slopes and talus on steeper slopes.

\section{Structure}

Rocks within the El Dorado Wilderness Study Area are strongly faulted and tilted as a result of late Tertiary deformation related to extensional tectonics (Anderson, 1971). The northern part of the El Dorado Mountains is cut by numerous mostly north-trending faults with displacements ranging from tens of feet to as much as $2,000 \mathrm{ft}$. These faults dip moderately to steeply to the west and merge at shallow depth in a complex low-angle detachment zone (Anderson, 1971). These faults have rotated the fault blocks to the east, so moderate to steep eastern dips predominate in the volcanic section. Angular unconformity between the Mount Davis Volcanics and the underlying tuff of Bridge Spring marks the beginning of this extensional faulting at about $14 \mathrm{Ma}$. This tectonism continued throughout emplacement of the Mount Davis Volcanics and post-dates the youngest flows of this unit.

The structure of the El Dorado Mountains in the vicinity of the Ireteba Peaks Wilderness Study Area lacks the features of thin-skin extensional faulting of the El Dorado Wilderness Study Area. The Ireteba Peaks Wilderness Study Area is underlain by a relatively coherent horst comprised of Precambrian and Tertiary crystalline rocks bounded by faults on the east and west sides of the range. This part of the El Dorado Mountains may represent a footwall or lower plate of the aforementioned detachment zone.

\section{Geochemical Studies}

A reconnaissance geochemical survey of the El Dorado and Ireteba Peaks Wilderness Study Areas was conducted in April, 1987. Samples of drainage sediment were collected at 66 sites on streams draining the wilderness study area and vicinity. Stream-sediment samples represent a composite of material eroded from the drainage basin of the stream sampled. Panned-concentrate samples derived from stream sediment contain selectively concentrated minerals that may be ore-related and may include elements not easily detected in stream-sediment samples. 
Three samples were collected at each site. One of the samples was air dried and then sieved through an 80 -mesh $(0.177-\mathrm{mm})$ stainless-steel sieve to obtain a "streamsediment sample." The portion that passed through the screen was later pulverized to minus-100 mesh $(0.149 \mathrm{~mm})$ prior to analysis. For the other two samples at each site, enough stream sediment was screened through a 10 -mesh $(2 \mathrm{~mm})$ sieve to obtain about $20 \mathrm{lb}$. The minus-10-mesh samples were panned to remove most of the quartz, feldspar, clay-sized material, and organic matter. One of these panned-concentrate samples was further concentrated by a series of steps that utilized bromoform (specific gravity 2.8 ) and magnetic separations to produce a "nonmagnetic heavy-mineral-concentrate sample," which will generally be referred to as simply a "concentrate sample." The concentrate sample includes most nonmagnetic ore minerals and accessory minerals such as sphene, zircon, apatite, and rutile. Prior to analysis the concentrate sample was pulverized to minus-100 mesh. The other panned-concentrate sample received no further treatment before chemical analysis for gold and is termed a "raw panned-concentrate sample" or "raw concentrate sample."

The stream-sediment and nonmagnetic heavy-mineral-concentrate samples were analyzed by emission spectrography for calcium, iron, magnesium, titanium, arsenic, silver, gold, boron, barium, beryllium, bismuth, cadmium, cobalt, chromium, copper, lanthanum, manganese, molybdenum, niobium, nickel, lead, antimony, scandium, tin, strontium, thorium, vanadium, tungsten, yttrium, zinc, and zirconium. In addition, the nonmagnetic heavy-mineral-concentrate samples were analyzed for phosphorus, sodium, gallium, germanium, palladium, and platinum by emission spectrography. Also, the stream-sediment samples were analyzed for gold by graphite-furnace atomic absorption, for uranium by ultraviolet fluorimetry, and for arsenic, bismuth, cadmium, antimony, and zinc by inductively coupled plasma spectroscopy. The raw concentrate samples were analyzed for gold by flame atomic absorption. Analytical data, sampling sites, and references to analytical methods are presented by McHugh and others (1988).

Table 1 lists selected elements determined in each sample type, the lower and upper limits of determination, the range of concentrations, the 50th and 95 th percentile concentrations, and the threshold (highest background) concentrations. Threshold concentrations were established by visual and statistical examination of the data, by comparison of the data with data from nearby wilderness study areas (Million Hills and Lime Canyon), and by reference to bedrock concentrations listed by Rose and others, $(1979$, p. 549-581).

Results

Of primary importance in the evaluation of the geochemical data is evidence that mineralizing processes extended beyond the areas of mining and prospecting that are adjacent to the El Dorado and Ireteba Peaks Wilderness Study Areas. Stream-sediment samples from throughout both wilderness study areas have mildly anomalous zinc concentrations; other elements show widespread patterns. Arsenic concentrations are anomalous throughout the eastern part of the El Dorado Wilderness Study Area. Cobalt concentrations are anomalous over much of the El Dorado Wilderness Study Area and the northern end of the Ireteba Peaks Wilderness Study Area. Tin is present in mildly anomalous concentrations in the southwestern to central parts of the El Dorado Wilderness Study Area and the northern part of the Ireteba Peaks Wilderness Study Area. Niobium concentrations are anomalous in concentrate samples from the Ireteba Peaks Wilderness Study Area except for those from the west side.

The wilderness study areas may be divided into five subareas, shown on figs. 4 and 5, having distinctive geochemical characteristics which along with interpretations are summarized in table 2. 
Table 1. Statistics for selected elements in drainage samples collected in and near the El Dorado and Ireteba Peaks Wilderness Study Areas, Clark County, Nevada

[Results based on 66 samples. Concentrations determined by emission spectrography except As-i, Bi-i, Cd-i, Sb-i, and $\mathrm{Zn}$-i determined by inductively coupled plasma spectroscopy, Au-a determined by atomic absorption, and U-f determined by ultraviolet fluorimetry. $\mathrm{N}$, not detected at lower limit of determination; $\mathrm{L}$, detected below lower limit of determination; G, greater than upper limit of determination; <, less than lower limit of determination; ---, upper limit is open ended]

\begin{tabular}{|c|c|c|c|c|c|}
\hline Elements & Limits of determination, ppm & Range, ppm & Percentiles, ppm & $\begin{array}{l}\text { Threshold } \\
\text { concentration, }\end{array}$ & $\begin{array}{l}\text { Number of } \\
\text { samples with }\end{array}$ \\
\hline & Lower $\quad$ Upper & Min Max & 50th 95th & ppm & $\begin{array}{l}\text { anomalous } \\
\text { concentrations }\end{array}$ \\
\hline
\end{tabular}

Minus-80-mesh stream-sediment samples

\begin{tabular}{|c|c|c|c|c|c|c|c|c|}
\hline $\mathbf{A g}$ & 0.5 & 5,000 & $\mathbf{N}$ & 1.5 & $\mathbf{N}$ & $\mathbf{N}$ & $\mathbf{N}$ & 2 \\
\hline As-i & 5 & 20,000 & $<$ & 33 & L & 14 & 9 & 10 \\
\hline $\mathrm{Au}-\mathrm{a}$ & 0.001 & --. & $<$ & 0.033 & 0.001 & 0.0045 & 0.002 & 12 \\
\hline $\mathrm{Bi}-\mathrm{i}$ & 2 & 20,000 & $<$ & 2 & $<$ & $<$ & $<$ & 1 \\
\hline Cd-i & 0.1 & 1,000 & 0.3 & 2.8 & 0.9 & 1.8 & 1.9 & 1 \\
\hline Co & 5 & 2,000 & 5 & 70 & 20 & 70 & 30 & 13 \\
\hline $\mathrm{Cu}$ & 5 & 20,000 & 15 & 100 & 30 & 70 & 50 & 6 \\
\hline $\mathrm{La}$ & 20 & 1,000 & 20 & 300 & 70 & 100 & 100 & 3 \\
\hline Mo & 5 & 2,000 & $\mathbf{N}$ & 5 & $\mathrm{~N}$ & $\mathbf{N}$ & $\mathbf{N}$ & 3 \\
\hline $\mathrm{Ni}$ & 5 & 5,000 & 15 & 200 & 70 & 200 & 150 & 5 \\
\hline $\mathrm{Pb}$ & 10 & 20,000 & 15 & 100 & 20 & 50 & 50 & 3 \\
\hline Sb-i & 2 & 20,000 & $<$ & 3 & $<$ & $<$ & $<$ & 1 \\
\hline Sn & 10 & 1,000 & $\mathbf{N}$ & L & $\mathbf{N}$ & L & $\mathrm{N}$ & 14 \\
\hline U-f & 0.1 & 1,000 & 0.6 & 12 & 1.1 & 3.45 & 2.9 & 6 \\
\hline $\mathrm{Zn}$ & 200 & 10,000 & $\mathbf{N}$ & $\mathrm{L}$ & $\mathrm{L}$ & L & $\mathbf{N}$ & 41 \\
\hline $\mathrm{Zn}$-i & 2 & 18,000 & 33 & 96 & 61 & 86 & 79 & 8 \\
\hline
\end{tabular}

Nonmagnetic heavy-mineral-concentrate samples

\begin{tabular}{|c|c|c|c|c|c|c|c|c|}
\hline Ag & 1 & 10,000 & $\mathbf{N}$ & 5 & $\mathbf{N}$ & L & $\mathbf{N}$ & 4 \\
\hline As & 500 & 20,000 & $\mathbf{N}$ & 500 & $\mathbf{N}$ & $\mathbf{N}$ & $\mathbf{N}$ & 1 \\
\hline $\mathbf{B a}$ & 50 & 10,000 & 150 & G & 700 & G & 3,000 & 15 \\
\hline $\mathrm{Be}$ & 2 & 2,000 & $\mathbf{N}$ & 5 & $\mathbf{N}$ & 2 & L & 6 \\
\hline $\mathrm{Bi}$ & 20 & 2,000 & $\mathbf{N}$ & 50 & $\mathbf{N}$ & $\mathbf{N}$ & $\mathbf{N}$ & 2 \\
\hline Co & 20 & 5,000 & $\mathbf{N}$ & 30 & $\mathbf{N}$ & L & $\mathbf{N}$ & 5 \\
\hline $\mathrm{Cu}$ & 10 & 50,000 & $\mathbf{N}$ & 200 & $\mathbf{N}$ & 75 & 30 & 7 \\
\hline $\mathrm{Ga}$ & 10 & 1,000 & $\mathbf{N}$ & 100 & $\mathbf{N}$ & 10 & L & 4 \\
\hline $\mathrm{La}$ & 100 & 2,000 & $\mathbf{N}$ & 2,000 & 300 & 1,500 & 1,000 & 6 \\
\hline Mo & 10 & 5,000 & $\mathbf{N}$ & 70 & $\mathbf{N}$ & 12 & L & 9 \\
\hline $\mathrm{Nb}$ & 50 & 5,000 & $\mathbf{N}$ & 70 & L & 50 & $\bar{L}$ & 13 \\
\hline $\mathrm{Ni}$ & 10 & 10,000 & $\mathbf{N}$ & 50 & $\overline{\mathbf{N}}$ & 15 & 10 & 6 \\
\hline $\mathrm{Pb}$ & 20 & 50,000 & $\mathbf{N}$ & 10,000 & 25 & 1,500 & 700 & 5 \\
\hline Sn & 20 & 2,000 & $\mathbf{N}$ & 100 & $\mathbf{N}$ & 20 & L & 7 \\
\hline Th & 200 & 5,000 & $\mathbf{N}$ & L & $\mathbf{N}$ & $\mathbf{N}$ & $\mathbf{N}$ & 2 \\
\hline $\mathbf{W}$ & 50 & 20,000 & $\mathbf{N}$ & 300 & $\mathbf{N}$ & L & $\mathbf{N}$ & 8 \\
\hline$Y$ & 20 & 5,000 & 70 & 1,000 & 200 & 500 & 500 & 2 \\
\hline
\end{tabular}

Raw panned-concentrate samples

\begin{tabular}{lllllll}
\hline $\mathrm{Au}-\mathrm{a}$ & $0.05^{*}$ & -- & $<$ & 1.1 & $<$ & 0.355
\end{tabular}

*Based on 10-g sample 


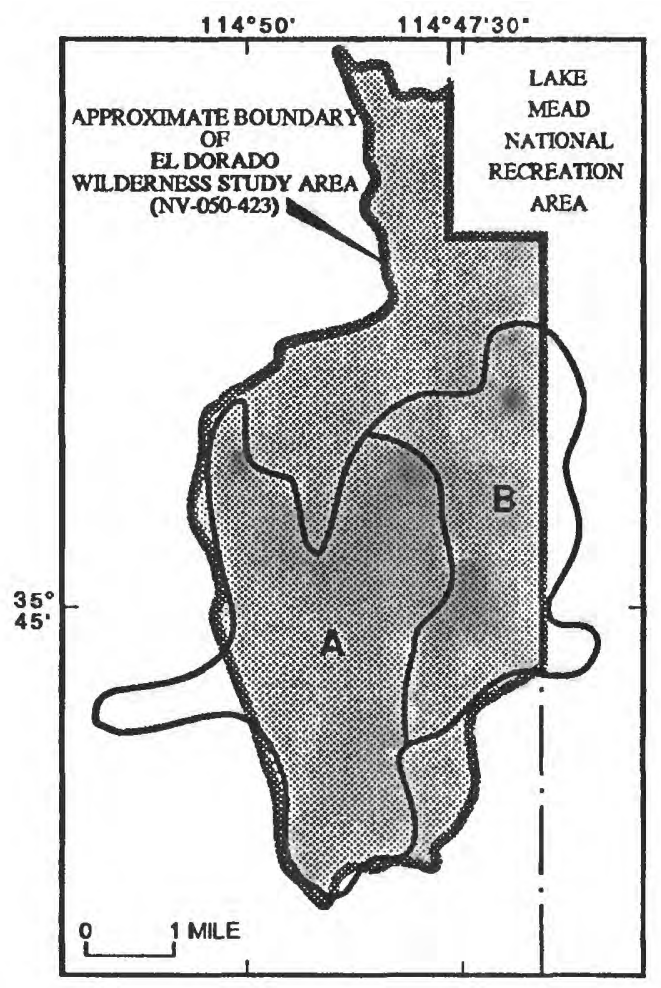

Figure 4. Map showing geochemical anomalies of El Dorado Wilderness Study Area, Clark County, Nevada.

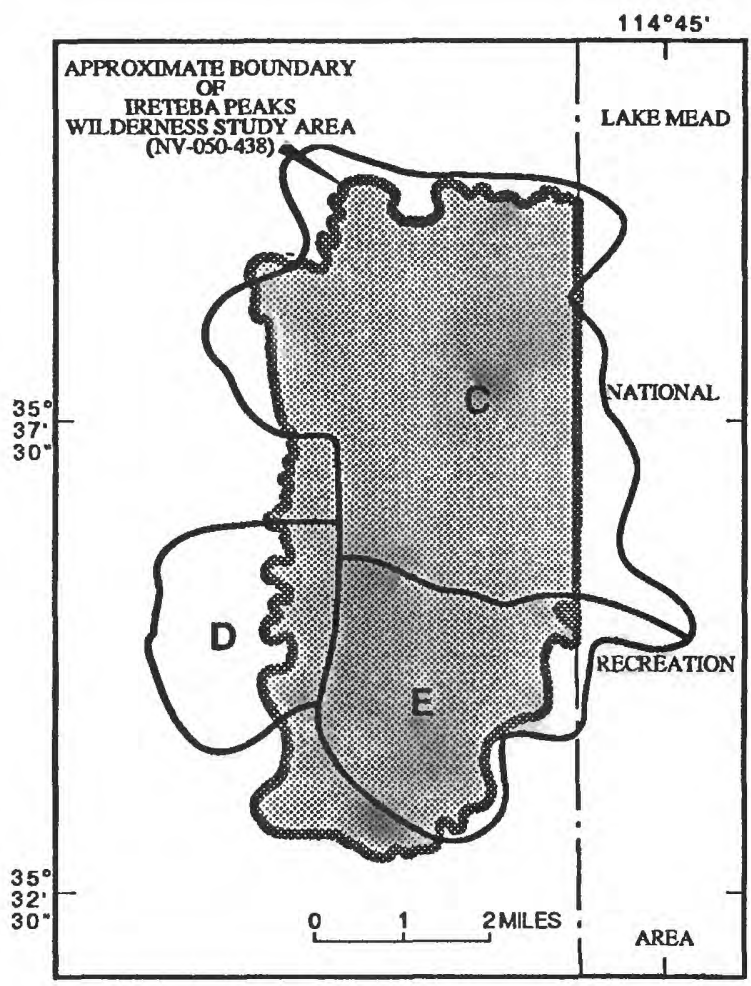

Figure 5. Map showing geochemical anomalies of Ireteba Peaks Wilderness Study Area, Clark County, Nevada. 
Table 2. Summary of geochemical characteristics of areas of the El Dorado and Ireteba Peaks Wilderness Study Areas, Clark County, Nevada, based on analyses of samples of stream sediment and panned concentrate derived from stream sediment

\begin{tabular}{|c|c|c|c|}
\hline $\begin{array}{l}\text { Area } \\
\text { (figs.4, 5) }\end{array}$ & Bedrock geology & $\begin{array}{l}\text { Elements present in anomalous } \\
\text { concentrations, in order of frequency }\end{array}$ & $\begin{array}{l}\text { Interpreted source of } \\
\text { geochemical signature }\end{array}$ \\
\hline $\mathbf{A}$ & $\begin{array}{l}\text { Tertiary volcanic } \\
\text { rocks }\end{array}$ & $\begin{array}{l}\mathrm{Zn}, \mathrm{Au}, \mathrm{Ag}, \mathrm{Pb} \\
\mathrm{Co}, \mathrm{Ni}, \mathrm{Cu} \\
\mathrm{Sn}, \mathrm{Be}, \mathrm{Bi}, \mathrm{La}\end{array}$ & $\begin{array}{l}\text { Hydrothermal mineralization } \\
\text { Mafic volcanic rocks } \\
\text { Felsic volcanic rocks }\end{array}$ \\
\hline B & $\begin{array}{l}\text { Precambrian metamorphic } \\
\text { rocks and Tertiary } \\
\text { volcanic rocks }\end{array}$ & $\begin{array}{l}\text { As, Ba, } \mathrm{Zn}, \mathrm{Co}, \mathrm{Ni}, \mathrm{Au}, \mathrm{W}, \mathrm{Cu}, \mathrm{Sb} \\
\mathrm{Nb}, \mathrm{La}\end{array}$ & $\begin{array}{l}\text { Hydrothermal mineralization } \\
\text { Pegmatites }\end{array}$ \\
\hline C & $\begin{array}{l}\text { Precambrian metamorphic } \\
\text { rocks and Tertiary } \\
\text { granite }\end{array}$ & $\begin{array}{l}\mathrm{Sn}, \mathrm{U}, \mathrm{La}, \mathrm{Y}, \mathrm{Nb}, \mathrm{Th} \\
\mathrm{Zn}, \mathrm{Mo}, \mathrm{Co}, \mathrm{Cu}, \mathrm{Ni}, \mathrm{W}, \mathrm{Au}, \mathrm{Cd}, \mathrm{Pb}\end{array}$ & $\begin{array}{l}\text { Pegmatites } \\
\text { Hydrothermal mineralization }\end{array}$ \\
\hline D & $\begin{array}{l}\text { Tertiary granite and } \\
\text { Precambrian } \\
\text { metamorphic rocks }\end{array}$ & $\begin{array}{l}\mathrm{Au}, \mathrm{Zn}, \mathrm{Cu}, \mathrm{Mo} \\
\mathrm{Be}, \mathrm{Bi}\end{array}$ & $\begin{array}{l}\text { Hydrothermal mineralization } \\
\text { Pegmatites }\end{array}$ \\
\hline $\mathbf{E}$ & $\begin{array}{l}\text { Tertiary granite and } \\
\text { Precambrian } \\
\text { metamorphic rocks }\end{array}$ & $\begin{array}{l}\mathrm{Ba}, \mathrm{Zn}, \mathrm{Au}, \mathrm{Mo}, \mathrm{Pb}, \mathrm{Cu}, \mathrm{W}, \mathrm{Ga}, \mathrm{Ag}, \mathrm{Ni} \\
\mathrm{Nb}, \mathrm{La}, \mathrm{Sn}\end{array}$ & $\begin{array}{l}\text { Hydrothermal mineralization } \\
\text { Pegmatites }\end{array}$ \\
\hline
\end{tabular}

Area A comprises the southwestern part of the El Dorado Wilderness Study Area (fig. 4) and some adjacent land and is underlain by Tertiary volcanic rocks. Evidence of prospecting is scarce in the parts of area A within the boundary of the wilderness study area. However, extensive prospecting and mining took place as near as $1,000 \mathrm{ft}$ south of area $\mathrm{A}$, including the extraction of more than $\$ 3,500,000$ worth of ore from the Techatticup Mine, the largest producer in the Eldorado Canyon district (Longwell and others, 1965, p. 118). Gold was the major commodity produced at the Techatticup Mine and at most mines in the district. The east-west trending Nelson fault zone (Volborth, 1973 , p. 19, 20) separates highly mineralized Tertiary granite on the south side of the fault from apparently unmineralized Tertiary volcanic rocks on the north side. However, anomalous gold and silver concentrations in samples from area A suggest that mineralization may have occurred north of the Nelson fault zone, also.

Anomalous cobalt, nickel, and copper concentrations in samples from area A occur exclusively in stream-sediment samples and are attributed to the presence of mafic volcanic rocks (table 2). The relation of anomalous concentrations of cobalt, nickel, and copper to unknown mineralization in area $\mathrm{A}$ cannot be ruled out, however, because these elements are part of the mineralization signature in areas B and C. Except for area A, anomalous concentrations of cobalt, nickel, and copper are usually in concentrate samples. Ferromagnesian minerals are theoretically removed from the concentrate sample by the magnetic separation, although in practice the magnetic separation is not perfect. However, concentrate samples from this study contain a maximum of only a few tenths of a percent of ferromagnesian minerals. Therefore, the anomalous concentrations of cobalt, nickel, and copper in concentrate samples from this study probably can be attributed to pyrite or other mineralization-related minerals. By inference then, mineralization cannot be ruled out as the source for anomalous concentrations of cobalt, nickel, and copper in stream-sediment samples from area A.

Beryllium concentrations in concentrate samples from area A are mildly anomalous; beryllium, along with tin, bismuth, and lanthanum are attributed to the 
presence of felsic volcanic rocks (table 2). The beryllium must be present in some mineral other than beryl because beryl generally accompanies low specific-gravity minerals during the heavy-liquid separation. Pegmatites have not been recognized in area A.

Area B comprises the east-central part of El Dorado Wilderness Study Area and some adjacent terrain (fig. 4). Area B is underlain by Tertiary volcanic rocks and Precambrian metamorphic rocks. Area B is geochemically distinct from area A. The greatest geochemical distinction is the highly anomalous concentrations of barium in concentrate samples from area B, but other distinctions are apparent as well. Anomalous concentrations of beryllium and silver are absent from area $\mathrm{B}$, in contrast to area $\mathrm{A}$. Cobalt and nickel concentrations are mildly anomalous in concentrate samples from area $B$ instead of in stream-sediment samples as in area A. Arsenic concentrations are anomalous in area B and in the northern tip of the El Dorado Wilderness Study Area, in contrast to area $A$ and elsewhere in either wilderness study area.

The significance of the arsenic anomaly in area $\mathrm{B}$, in terms of mineralization, is increased by the fact the only concentrate sample in this study with a detectable and therefore anomalous concentration of arsenic is from the east side of area $B$. The concentration of arsenic in a stream-sediment sample from this area is $33 \mathrm{ppm}$ (parts per million), the highest concentration in any stream-sediment sample from this study. The only detectable concentration of antimony in any sample from this study is in a streamsediment sample from area B. Anomalous concentrations of tungsten in two concentrate samples are due to the presence of scheelite. The grains of scheelite in one of these two samples are almost all molybdenum rich, as determined by illumination with short-wave ultraviolet light.

Anomalous concentrations of arsenic, barium, zinc, cobalt, nickel, gold, tungsten, copper, and antimony in area B suggest a geochemical signature related to hydrothermal mineralization (table 2). Pegmatites occur with Precambrian gneisses and schists in the Eldorado Mountains (Volborth, 1973, p. 5); anomalous concentrations of niobium and lanthanum may indicate the presence of pegmatites in area $B$.

Area $C$ comprises the northern half of the Ireteba Peaks Wilderness Study Area (fig. 5). Area $\mathrm{C}$ is underlain by Precambrian metamorphic rocks and Tertiary granite. Volborth (1973, p. 5) noted that some of the pegmatites associated with Precambrian gneisses and schists in the Eldorado Mountains are complex pegmatites. Area $\mathrm{C}$ has the strongest geochemical signature for mineralized pegmatites of any part of the El Dorado and Ireteba Peaks Wilderness Study Areas. Anomalous concentrations of uranium, thorium, and yttrium occur only in samples from this area and are accompanied by anomalous concentrations of tin, lanthanum, and niobium. Anomalous concentrations of gold are notably absent except in two samples near the southern edge of area C. Anomalous concentrations of cobalt and copper in concentrate samples suggest a relation to processes of hydrothermal mineralization. Cobalt, copper, and nickel are present in anomalous amounts in some stream-sediment samples from area $\mathrm{C}$. Precambrian diabase is present in area $\mathrm{C}$ and must be considered as a possible source, in addition to mineralization, for the anomalous concentrations of cobalt, copper, and nickel. The only anomalous concentration of cadmium in the study is in a sample from area $\mathrm{C}$ and lead is mildly anomalous in one stream-sediment sample.

Area D comprises most of the southern half of the Ireteba Peaks Wilderness Study Area west of the drainage divide formed by the north-south ridge that includes the Ireteba Peaks (fig. 5). Area D is underlain by Tertiary granite and Precambrian metamorphic rocks. Pegmatites are especially numerous in the foothills of Ireteba Peaks and thus in the vicinity of area $D$; these pegmatites sometimes contain niobium and tantalum (Volborth, 1969, p. 2/5). About a ton of beryl-bearing rock was mined from a pegmatite in the same area (Longwell and others, 1965, p. 206). The presence of mildly anomalous concentrations of beryllium and bismuth in concentrate samples may reflect the 
pegmatites, although beryl is not generally a component of nonmagnetic heavy-mineralconcentrate samples because of its low specific gravity.

Gold concentrations are anomalous in samples from 5 of the 6 sampling sites in area D. Detectable zinc, as determined by emission spectrography, is present in most stream-sediment samples from area D, as is true throughout both wilderness study areas. Copper and molybdenum are present in mildly anomalous concentrations. In terms of hydrothermal mineralization, the intensity of the geochemical signature in area D is mild compared to areas A, B, C, and E, but the presence of almost ubiquitous gold dictates that area $\mathrm{D}$ should not be discounted.

Area $\mathrm{E}$ comprises the southeastern part of the Ireteba Peaks Wilderness Study Area (fig. 5). Area E is underlain by Tertiary granite and Precambrian metamorphic rocks. The geochemical signature of area $E$ closely resembles that of area $B$ because of the highly anomalous concentrations of barium in concentrate samples, the common occurrence of anomalous concentrations of gold, mildly anomalous zinc concentrations, relative lack of silver concentrations, and the presence of anomalous concentrations of tungsten and nickel in concentrate samples. Area E differs from area B in that molybdenum is anomalous in concentrate samples from area $\mathrm{E}$, lead is highly anomalous in concentrate samples from area $\mathrm{E}$, copper is anomalous in several concentrate samples from area $E$, and anomalous concentrations of cobalt are absent from area $E$. In addition, only a small percentage of the scheelite grains in concentrate samples from area $\mathrm{E}$ are molybdenum rich, in contrast to samples from area B. The only two samples in this study that contain anomalous concentrations of gallium are concentrate samples from area $E$. This suite of elements is interpreted to represent hydrothermal mineralization (table 2). A greater proportion of concentrate samples (9 of 12) from area E contains anomalous concentrations of niobium than from any of the other areas in this study. These ubiquitous concentrations of niobium, coupled with a few anomalous concentrations of lanthanum and tin suggest that pegmatites are reflected. The geochemical patterns in area E suggest the overprinting of the hydrothermal mineralization signature (fig. 5 and table 2) on a larger pattern best represented by anomalous niobium concentrations.

Areas $\mathrm{B}$ and $\mathrm{E}$ appear to be the areas where hydrothermal mineralization was most intense as evidenced by the number of elements indicative of hydrothermal mineralization that are present in anomalous concentrations and by the magnitude of the concentrations. These geochemical patterns, especially those of barium, are spatially related to areas underlain by Precambrian metamorphic rocks.

The anomalous concentrations of cobalt, copper, and nickel in stream-sediment samples might reflect the presence of mafic rocks. However, mildly anomalous concentrations of these elements in concentrate samples are more likely due to the presence of minerals that are the result of ore-forming processes or hydrothermal alteration. Additional geochemical evidence exists for this conclusion; a sample of water collected from a dug well in Techatticup Wash, about 4,000 ft east of the Techatticup Mine (fig. 2) contains a highly anomalous $30 \mu \mathrm{g} / \mathrm{L}$ of cobalt (McHugh and Nowlan, 1989). This anomalous concentration of cobalt in groundwater suggests that cobalt is an important part of the mineralizing system in the Nelson area.

The hydrothermal-mineralization geochemical signatures (table 2) have characteristics that are compatible with the very general mineral-deposit model of felsicintrusion-associated veins (Cox, 1986) and with any of several models for epithermal veins associated with bimodal volcanism (Mosier and others, 1986a; 1986b; 1986c). The geochemical signatures, coupled with the presence of nearby vein deposits, indicate that mineralizing processes operated throughout most of the El Dorado and Ireteba Peaks Wilderness Study Areas.

Pegmatites (occasionally complex) occur within Precambrian gneisses and schists in the Eldorado Mountains (Volborth, 1973, p. 5). Areas B-E all have geochemical signatures that are probably related to pegmatites. 
The geochemical signature in area $\mathrm{A}$, interpreted in table 2 as being related to felsic volcanic rocks, has some of the characteristics of rhyolite-hosted tin deposits (Reed and others, 1986). Some of the volcanic units from area A contain highly siliceous rhyolites, a characteristic of tin rhyolites. However, concentrations of tin in samples from anywhere in either wilderness study area are far less than what would be expected if rhyolite-hosted tin deposits were present (Reed and others, 1986).

\section{Mineral and Energy Resource Potential of the El Dorado Wilderness Study Area}

Geologic and geochemical studies indicate that large parts of the El Dorado Wilderness Study Area have high to moderate resource potential for gold, silver, lead, zinc, copper, and tungsten. Known mineralization in the area is mainly gold and silver in quartz and calcite veins often cutting fractured and brecciated rock. These veins also carry significant amounts of lead, zinc, and copper. Alteration and mineralization are most intense along the extreme southern boundary of the study area, but geochemical analyses of stream sediment suggest significant hydrothermal alteration throughout most of the southern two-thirds of the study area. The southern part of the study area has high resource potential for gold, silver, copper, lead, and zinc in quartz and calcite veins, certainty level C. Anomalous gold, silver, lead, and zinc in the stream sediment samples in the central part of the study area indicate moderate resource potential for these commodities, certainty level C. There is low resource potential for gold, silver, lead, and zinc throughout the rest of the study area, certainty level B. Stream-sediment samples from the area underlain by Precambrian rocks along the east side of the study area contain an anomalous suite of elements including arsenic, barium, tungsten, niobium, and lanthanum that may be derived from pegmatites. There is moderate resource potential for gold, zinc, cobalt, nickel, tungsten, niobium, and lanthanum, certainty level C, along the east side of the study area. A uranium occurrence from this area was reported by Garside (1973) but could not be confirmed for this study. Geochemical studies do not reveal anomalous uranium in this area, so the resource potential for uranium in the Precambrian rocks is low, certainty level B.

Sand and gravel occur in small deposits suitable for local use; there is low potential for significant resources of these commodities, certainty level C. The El Dorado Wilderness Study Area lies within an area considered by Sandberg (1983) to have low potential for oil and gas resources. In this region, however, hydrocarbon source or reservoir rocks are limited to Tertiary sedimentary basins that flank the mountain ranges. Within the study area, Precambrian schist, gneiss, and granite crop out or everywhere underlie exposures of the Tertiary volcanic and sedimentary rocks at shallow depths. Therefore, there is no potential for oil and gas resources in the study area, certainty level D.

\section{Mineral and Energy Resource Potentlal of the Ireteba Peaks Wilderness Study Area}

Geologic and geochemical studies suggest the presence of significant mineralization in the Ireteba Peaks Wilderness Study Area. Known mineralization in and near the study area is mainly in the Precambrian metamorphic rocks, and geochemical analyses of stream sediments within the study area indicate anomalous concentrations of elements occur mainly in areas underlain by Precambrian rocks. Anomalous values of uranium, thorium, yttrium, tin, beryl, bismuth, lanthanum, and niobium are found along the western and northern boundaries of the study area and suggest the presence of mineralized pegmatites in the Precambrian metamorphic rocks. There is low resource potential for uranium, niobium, thorium, lanthanum, and beryl, certainty level $\mathrm{C}$, along the western and northern parts of the study area.

The southern and northern parts of the study area have an anomalous suite of elements in stream sediments that include gold, silver, molybdenum, copper, tungsten, 
lead, and zinc that appear to be related to hydrothermal mineralization. These areas, underlain by Tertiary granitic rocks, have moderate resource potential for these elements, certainty level $\mathrm{C}$.

The Ireteba Peaks Wilderness Study Area lies within an area considered by Sandberg (1983) to have low potential for oil and gas resources. In this region, however, hydrocarbon source or reservoir rocks are limited to Tertiary sedimentary basins that flank the mountain ranges. Precambrian schist and Tertiary granitic rocks, however, underlie the entire study area. Therefore, there is no potential for oil and gas resources in the study area, certainty level D.

\section{REFERENCES CITED}

Anderson, R.E., 1971, Thin skin distension in Tertiary rocks of southeastern Nevada: Geological Society of America Bulletin, v. 82, p. 43-58.

Anderson, R.E., Longwell, C.R., Armstrong, R.L., and Marvin, R.F., 1972, Significance of $\mathrm{K}$-Ar ages of Tertiary rocks from the Lake Mead region, Nevada-Arizona: Geological Society of America Bulletin, v. 83, p. 273-288.

Ashbaugh, Don, 1959a, No. 190 in a series-Eldorado, part 1, in Ghost towns of Nevada: Las Vegas Review Journal, Sept. 20, p. 22-23.

1959 b, No. 191 in a series-Eldorado, part 2, in Ghost towns of Nevada : Las Vegas Review Journal, Sept. 27, p. 47-48.

1959 c, No. 192 in a series-Eldorado, part 3, in Ghost towns of Nevada : Las Vegas Review Journal, Oct. 4, p. 30-31.

1959d, No. 193 in a series-Eldorado, conclusion, in Ghost towns of Nevada: Las Vegas Review Journal, Oct 11, p. 30-31.

Beikman, H.M., Hinkle, M.E., Frieders, Twila, Marcus, S.M., and Edward, J.R., 1983, Mineral surveys by the Geological Survey and the Bureau of Mines of Bureau of Land Management Wilderness Study Areas: U.S. Geological Survey Circular 901,28 p.

Browne, J.R., 1868, Mineral resources of the States and Territories west of the Rocky Mountains: Government Printing Office, Washington, D.C., 674 p.

Callaghan, Eugene, 1939, Geology of the Searchlight district, Clark County, Nevada: U.S. Geological Survey Bulletin 906-D, 188 p.

Carlson, H.S., 1974, Nevada place names: University of Nevada Press, Reno, Nevada, $282 \mathrm{p}$.

Causey, J.D., 1988, Mineral resources of the Ireteba Peaks study area, Clark County, Nevada: U.S. Bureau of Mines Mineral Land Assessment Open-file Report MLA 46-88, $46 \mathrm{p}$.

Causey, J.D., and Miller, M.S., 1988, Mineral resources of the Eldorado study area, Clark County, Nevada: U.S. Bureau of Mines Mineral Land Assessment Open-file Report MLA 44-88, 48 p.

Couch, B.F., and Carpenter, J.A., 1943, Nevada's metal and mineral production (18591940, inclusive): University of Nevada Bulletin, vol. XXXVII, no. 4, 159 p.

Cox, D.P., 1986, Descriptive model of polymetallic veins, in Cox, D.P., and Singer, D.A., eds., Mineral deposit models: U. S. Geological Survey Bulletin 1693, p. 125.

Gallagher, P.J., 1941a, Past, present history of famed Eldorado Canyon in Clark County: Las Vegas (Nevada) Evening Review Journal, Jan. 23, p. 6.

$1941 b$, Past, present history of famed Eldorado Canyon in Clark County: Las Vegas (Nevada) Evening Review-Journal, Jan. 28, p. 5.

Garside, L.J., 1973, Radioactive mineral occurrences in Nevada: Nevada Bureau of Mines and Geology Bulletin 81, 121 p. 
Goudarzi, G.H., 1984, Guide to preparation of mineral survey reports on public lands: U.S. Geological Survey Open-File Report 84-787, 51 p.

Hansen, S.M., 1962, The geology of the Eldorado mining district, Clark County, Nevada: University of Missouri Ph. D. dissertation, $262 \mathrm{p}$.

Hansen, S.M., 1963, The geology of the Eldorado mining district, Clark County, Nevada: Dissertation Abstracts, v. 23, no. 7, p. 2491.

Hewett, D.F., Callaghan, Eugene, Moore, B.N., Nolan, T.B., Rubey, W.W., and Schaller, W.T., 1936, Mineral resources of the region around Boulder Dam: U. S. Geological Survey Bulletin 871, 197 p.

Hill, J.M., 1912, The mining districts of the western United States: U.S. Geological Survey Bulletin 507, $309 \mathrm{p}$.

Hillen, A.G., 1909, Mining operations in Eldorado district, Nevada: The Mining World, p. 1025-1028.

Kantor, Tedral, 1961, Geology of the east-central portion of the Nelson quadrangle, Clark County, Nevada: University of Missouri Master's thesis, $80 \mathrm{p}$.

Kern, R.R., Drobeck, P.A., and Jenkins, S.L., 1988, Geology of the Nelson district, in Weide, D.L., and Faber, M.L., eds., This extended land, geological journeys in the southern Basin and Range: Geological Society of America, Cordilleran Section meeting, Las Vegas, NV, University of Nevada, Las Vegas Department of Geoscience Special Publication No. 2, p. 67-73.

Lincoln, F.C., 1923, Mining districts and mineral resources of Nevada: Nevada Newsletter Publishing Company, Reno, Nevada, 295 p.

Longwell, C.R., 1963, Reconnaissance geology between Lake Mead and Davis Dam, Arizona-Nevada: U.S. Geological Survey Professional Paper 374-E, 51 p.

Longwell, C.R., Pampeyan, E.H., Bowyer, Ben, and Roberts, R.J., 1965, Geology and mineral deposits of Clark County, Nevada: Nevada Bureau of Mines and Geology Bulletin 62, 218 p., 16 plates.

Luning, R.H., Penley, H.M., Johnson, C.L., and Dotterrer, F.E., 1982, National uranium resource evaluation, Kingman quadrangle, Arizona, Nevada, and California: U.S. Department of Energy PGJ/F-137(82), 23 p.

McHugh, J.B., and Nowlan, G.A., 1989, Analytical results and sample locality maps for 12 water samples from springs and domestic wells near the El Dorado, Lime Canyon, and Million Hills Wilderness Study Areas, Clark County, Nevada: U.S. Geological Survey Open-File Report 89-301, 10 p.

McHugh, J.B., Bullock, J.H., Jr., Roemer, T.A., and Nowlan, G.A., 1989, Analytical results and sample locality map for stream-sediment and panned-concentrate samples from the El Dorado and Ireteba Peaks Wilderness Study Areas, Clark County, Nevada: U.S. Geological Survey Open-File Report 89-22, 19 p.

McKelvey, V.E., 1972, Mineral resource estimates and public policy: American Scientist, v. 60 , p. $32-40$.

Mosier, D.L., Berger, B.R., and Singer, D.A., 1986a, Descriptive model of Sado epithermal veins, in Cox, D.P., and Singer, D.A., eds., Mineral deposit models: U. S. Geological Survey Bulletin 1693, p. 154-157.

Mosier, D.L., Singer, D.A., and Berger, B.R., 1986b, Descriptive model of Comstock epithermal veins, in Cox, D.P., and Singer, D.A., eds., Mineral deposit models: U.S. Geological Survey Bulletin 1693, p. 150-153.

Mosier, D.L., Sato, Takeo, Page, N.J, Singer, D.A., and Berger, B.R., 1986c, Descriptive model of Creede epithermal veins, in Cox, D.P., and Singer, D.A., eds., Mineral deposit models: U. S. Geological Survey Bulletin 1693, p. 145-149.

Olson, J.C., and Hinrichs, E.N., 1960, Beryl-bearing pegmatites in the Ruby Mountains and other areas in Nevada and northwestern Arizona: U.S. Geological Survey Bulletin 1082-D, p. 135-200. 
Qualheim, B.J., 1978, Hydrogeochemical and stream sediment reconnaissance basic data report for Kingman NTMS quadrangle, Arizona, California, and Nevada: U.S. Department of Energy GJBX - 122'78, 26 p.

Ransome, F.L., 1907, Preliminary account of Goldfield, Bullfrog, and other mining districts in southern Nevada: U.S. Geological Survey Bulletin 303, 98 p.

Raymond, R.W., 1872, Statistics of mines and mining in the States and Territories west of the Rocky Mountains: U.S . House of Representatives Executive Document no. 10, 42nd Congress, 1st Session, 566 p.

1873, Statistics of mines and mining in the States and Territories west of the Rocky Mountains: U.S. House of Representatives Executive Document no. 210, 42nd Congress, 3rd Session, $550 \mathrm{p}$.

Reed, B.L., Duffield, Wendell, Ludington, S.D., Maxwell, C.H., and Richter, D.H., 1986, Descriptive model of rhyolite-hosted Sn, in Cox, D.P., and Singer, D.A., eds., Mineral deposit models: U. S. Geological Survey Bulletin 1693, p. 168.

Rose, A.W., Hawkes, H.E., and Webb, J.S., 1979, Geochemistry in mineral exploration, 2nd edition: London, Academic Press, $657 \mathrm{p}$.

Sandberg, C.A., 1983, Petroleum potential of wilderness lands in Nevada, in Miller, B.M., ed., Petroleum potential of wilderness lands in the western United States: U.S. Geological Survey Circular 902 A-P, p. H1-H11.

Smith, P.L., and Tingley, J.V., 1983a, A mineral inventory of the Esmeralda-Stateline Resource Area, Las Vegas District, Nevada: Nevada Bureau of Mines and Geology Open-File Report 83-11,173 p.

$1983 \mathrm{~b}$, Results of geochemical sampling within Esmeralda-Stateline Resource Area, Esmeralda, Clark, and southern Nye Counties, Nevada (portions of Death Valley, Goldfield, Kingman, Las Vegas, Mariposa and Tonopah $2^{\circ}$ sheets): Nevada Bureau of Mines and Geology Open-file Report 83-12, unnumbered pages.

The Mining World, 1908a, Nevada: vol. XXIX, no.2, p. 72. 1908b, Nelson: vol. XXIX, no. 12, p. 460. 1910, Eldorado: vol. XXXII, no. 14, p. 724.

U.S. Bureau of Land Management, 1983, Eldorado Mountains G-E-M resources area (GRA no. NV-37) technical report (WSA's NV 050-0423 and 050-0438): Great Basin GEM Joint Venture, contract YA-554-RFP2-1054, available from BLM, Denver, CO, $33 \mathrm{p}$.

U.S. Bureau of Mines and U.S. Geological Survey, 1980, Principles of a resource/reserve classification for minerals: U.S. Geological Survey Circular 831, 5 p.

Vanderburg, W.O., 1937, Reconnaissance of mining districts in Clark County, Nevada: U.S. Bureau of Mines Information Circular 6964, $81 \mathrm{p}$.

Volborth, Alexis, 1969, Geology of the Eldorado and Newberry ranges: Basin and Range Geology Field Conference, 2nd, Guidebook: Reno, MacKay School of Mines, University of Nevada, p. 2/1-2/9.

1973, Geology of the granite complex of the Eldorado, Newberry, and northern Dead Mountains, Clark County, Nevada: Nevada Bureau of Mines and Geology Bulletin $80,40 \mathrm{p}$. 
APPENDIXES 


\section{DEFINITION OF LEVELS OF MINERAL RESOURCE POTENTIAL AND CERTAINTY OF ASSESSMENT}

\section{LEVELS OF RESOURCE POTENTIAL}

H HICH mineral resource polential is assigned to areas where geologic, geochemical, and geophysical characteristics indicate a geologic environment favorable for resource occurrence, where interpretations of data indicate a high degree of likelihood for resource accumulation, where data support mineral-deposit models indicating presence of resources, and where evidence indicates that mineral concentration has taken place. Assignment of high resource potential to an area requires some positive knowledge that mineral-forming processes have been active in at least part of the area.

M MODERATE mineral resource potential is assigned to areas where geologic, geochemical, and geophysical characteristics indicate a geologic environment favorable for resource occurrence, where interpretations of data indicate reasonable likelihood for resource accumulation, and (or) where an application of mineral-deposit models indicates favorable ground for the specified type(s) of deposits.

L LOW mineral resource potential is assigned to areas where geologic, geochemical, and geophysical characteristics define a geologic environment in which the existence of resources is permissive. This broad category embraces areas with dispersed but insignificantly mineralized rock, as well as areas with little or no indication of having been mineralized.

N NO mineral resource potential is a calegory resenved for a specific type of resource in a well-defined area.

$U$ UNKNOWN mineral resource potential is assigned to areas where information is inadequate to assign a low, moderate, or high level of resource potential.

\section{LEVELS OF CERTAINTY}

A Available information is not adequate for determination of the level of mineral resource potential.

B Available information only suggests the level of mineral resource potential.

C Available information gives a good indication of the level of mineral resource potential.

D Available information clearly defines the level of mineral resource potential.

\begin{tabular}{|c|c|c|c|}
\hline$A$ & B & C & $\mathrm{D}$ \\
\hline \multirow{4}{*}{ UNKNOWN POTENTIAL } & $\begin{array}{c}\text { H/B } \\
\text { HIGH POTENTIAL }\end{array}$ & $\begin{array}{c}\text { H/C } \\
\text { HIGH POTENTIAL }\end{array}$ & $\begin{array}{c}\text { H/D } \\
\text { HICH POTENTIAL }\end{array}$ \\
\hline & $\begin{array}{c}\text { MB } \\
\text { MODERATE POTENTIAL }\end{array}$ & $\begin{array}{c}\text { MC } \\
\text { MODERATE POTENTIAL }\end{array}$ & $\begin{array}{c}\text { MD } \\
\text { MODERATE POTENTIAL }\end{array}$ \\
\hline & \multirow[t]{2}{*}{$\begin{array}{c}\text { L/B } \\
\text { LOW POTENTIAL }\end{array}$} & \multirow[t]{2}{*}{$\begin{array}{c}\text { L/C } \\
\text { LOW POTENTIAL }\end{array}$} & $\begin{array}{c}\text { U/D } \\
\text { LOW POTENTIAL }\end{array}$ \\
\hline & & & $\begin{array}{c}\text { N/D } \\
\text { NO POTENTIAL }\end{array}$ \\
\hline
\end{tabular}

LEVEL OF CERTAINTY

Abstracted with minor modifications from

Taytor, R.B., and Steven, T.A., 1983, Definition of minetal resource potential. Fconomic Gevlogy, v. 78, no. 6, p. 1268-1270.

Taylor, R.B., Stoneman, R.J., and Marsh, S.P., 1984, An assessment of the mineral resource potential of the San Isabel National Forest, south-central Colorado U.S Ceological Survey Bulletin 1638, p. 40-42.

Coudarzi, C.H., compiler, 1984, Cuide to preparalion of mincral suncy repons on public lands: U.S Ceological Suncy Open-File Report 84-0787, p. 7, 8 
RESOURCE/RESERVE CLASSIFICATION

\begin{tabular}{|c|c|c|c|c|c|}
\hline & \multicolumn{3}{|c|}{ IDENTIFIED RESOURCES } & \multirow{2}{*}{\multicolumn{2}{|c|}{$\frac{\text { UNDISCOVERED RESOURCES }}{\text { Probability Range }}$}} \\
\hline & \multicolumn{2}{|c|}{ Demonstrated } & \multirow{2}{*}{ Inferred } & & \\
\hline & Measured & Indicated & & Hypothetical & Speculative \\
\hline ECONOMIC & Rese & rves & $\begin{array}{l}\text { Inferred } \\
\text { Reserves }\end{array}$ & & \\
\hline $\begin{array}{l}\text { MARGINALLY } \\
\text { ECONOMIC }\end{array}$ & Mare & ginal & $\begin{array}{l}\text { Inferred } \\
\text { Marginal } \\
\text { Reserves }\end{array}$ & & \\
\hline $\begin{array}{c}\text { SUB- } \\
\text { ECONOMIC }\end{array}$ & $\begin{array}{r}\text { Demon } \\
\text { Subeco } \\
\text { Reso }\end{array}$ & $\begin{array}{l}\text { istrated } \\
\text { onomic } \\
\text { urces }\end{array}$ & $\begin{array}{l}\text { Inferred } \\
\text { Subeconomic } \\
\text { Resources }\end{array}$ & & \\
\hline
\end{tabular}

Major elements of mineral resource classification, excluding reserve base and inferred reserve base. Modified from McKelvey, V.E., 1972, Mineral rescurce estimates and public policy: American Scientist, v. 60, p. 32-40; and U.S. Bureau of Mines and U.S. Geological Survey, 1980, Principles of a resource/reserve classification for minerals: U.S. Ceological Survey Circular 831, p. 5. 
Terms and boundary ages used by the U.S. Geological Survey in this report

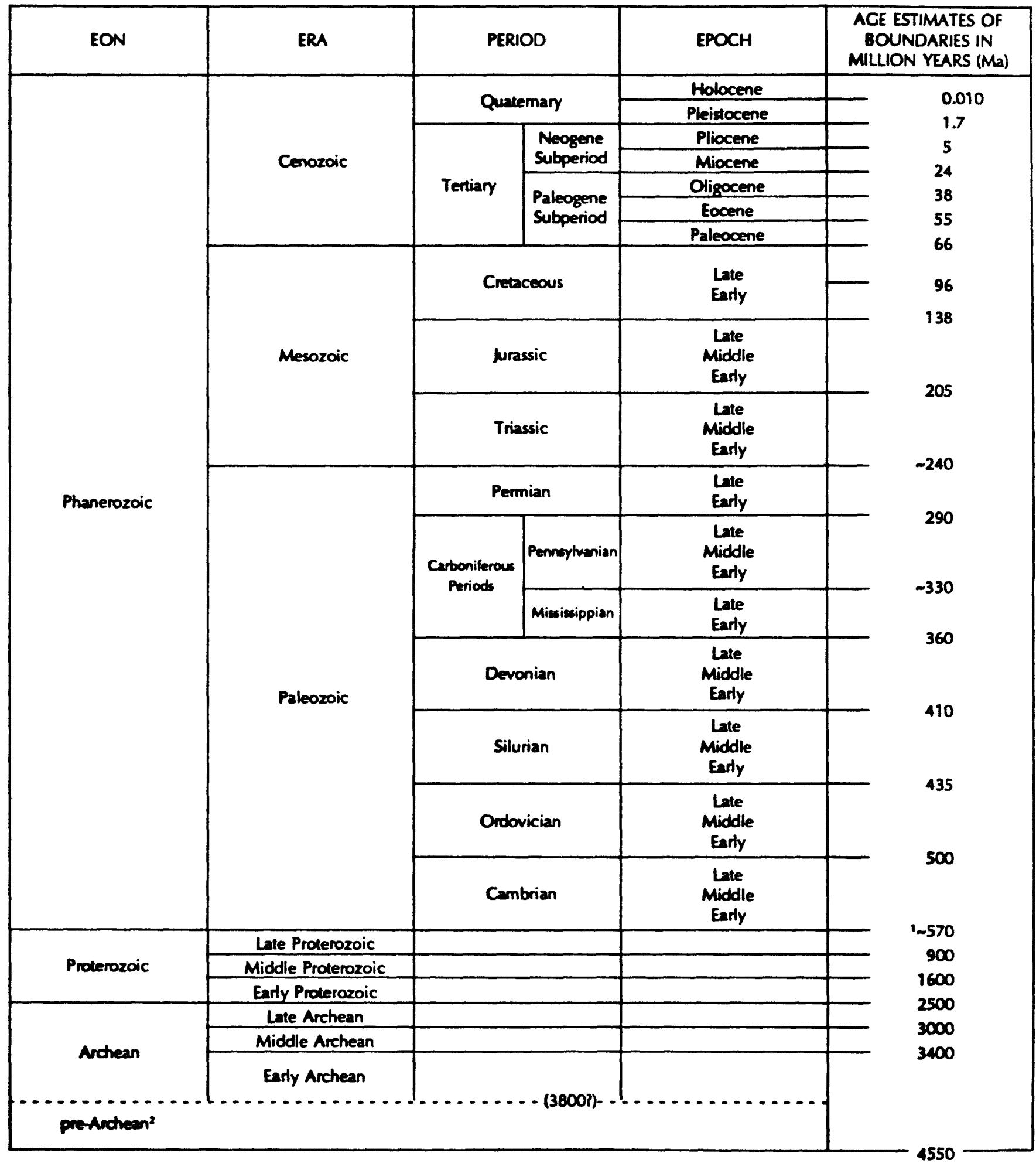

'Rocks older than $570 \mathrm{Ma}$ also called Precambrian, a time term without specific rank.

informal time term without specific rank. 